Review

\title{
Towards an Optimal Sample Delivery Method for Serial Crystallography at XFEL
}

\author{
Robert KY Cheng \\ leadXpro AG, Park Innovaare, CH-5234 Villigen, Switzerland; Robert.cheng@leadxpro.com
}

Received: 28 February 2020; Accepted: 17 March 2020; Published: 19 March 2020

\begin{abstract}
The advent of the X-ray free electron laser (XFEL) in the last decade created the discipline of serial crystallography but also the challenge of how crystal samples are delivered to X-ray. Early sample delivery methods demonstrated the proof-of-concept for serial crystallography and XFEL but were beset with challenges of high sample consumption, jet clogging and low data collection efficiency. The potential of XFEL and serial crystallography as the next frontier of structural solution by X-ray for small and weakly diffracting crystals and provision of ultra-fast time-resolved structural data spawned a huge amount of scientific interest and innovation. To utilize the full potential of XFEL and broaden its applicability to a larger variety of biological samples, researchers are challenged to develop better sample delivery methods. Thus, sample delivery is one of the key areas of research and development in the serial crystallography scientific community. Sample delivery currently falls into three main systems: jet-based methods, fixed-target chips, and drop-on-demand. Huge strides have since been made in reducing sample consumption and improving data collection efficiency, thus enabling the use of XFEL for many biological systems to provide high-resolution, radiation damage-free structural data as well as time-resolved dynamics studies. This review summarizes the current main strategies in sample delivery and their respective pros and cons, as well as some future direction.
\end{abstract}

Keywords: serial crystallography; XFEL; microcrystal; sample delivery; liquid jet; LCP jet; fixed target support; drop-on-demand; time-resolved; high-throughput

\section{Introduction}

A recent estimate has put the capitalized cost of putting a new drug onto the market at close to US $\$ 2.6$ billion, a $145 \%$ increase over a 10 -year period [1]. Drug development remains both risky and costly, with the success rate of clinical candidates reaching market approval from phase I at $13.8 \%$ [2]. The pharmaceutical industry must constantly innovate in order to deliver new and better quality drug candidates to clinical research. For example, high-throughput screening (HTS) is often used to identify initial chemotypes in early lead discovery, followed by lead optimization to produce preclinical candidates. HTS employs chemical libraries containing $>10^{9}$ compounds which only explores a small fraction of the total chemical space. Fragment-based drug discovery [3] (FBDD) and DNA-encoded libraries (DEL) $[4,5]$ are developed to more efficiently explore the chemical space, either by improving ligand efficiency (FBDD) or increasing the complexity of the chemical library (DEL) during HTS. Both technologies have proven to be revolutionary and demonstrated their power by successfully bringing candidate drugs either to market (for e.g., Vemurafenib, a v-Raf murine sarcoma viral oncogene homolog B1 (B-RAF) kinase inhibitor for the treatment of metastatic melanoma [6]) or to advanced clinical trials (for e.g., GSK2982772, a first-in-class inhibitor of receptor-interacting protein kinase 1 (RIPK1) for chronic inflammatory diseases [7]).

Structure-based drug design (SBDD) injects rational knowledge to complement the principally random nature of HTS. It has had a tremendous impact on the pharmaceutical industry and was 
used as early as in the 1990s to help develop Dorzolamide, Saquinavir and Zanamivir, inhibitors of carbonic anhydrase [8], human immunodeficiency viruses (HIV) protease [9] and neuraminidase [10] for the treatment of glaucoma, HIV and influenza virus infection respectively. SBDD utilizes protein three-dimensional (3D) structural information derived by experimental or bioinformatics methods (for e.g., homology modelling) [11,12]. Sequencing of the human genome has opened up vast possibilities for data mining and has led to genome-wide structural proteomic studies led by various consortiums [13]. These efforts have brought about an explosion of structural knowledge of many protein families including many disease targets. Precise mapping and re-construction of protein ligand binding pockets allow the application of computational methodology (docking, virtual screening, pharmacokinetics modelling, artificial intelligence, and machine learning) to optimize ligand potency, specificity and in vivo efficacy [14] to speed up drug discovery efforts.

X-ray crystallography continues to dominate as the experimental method that produces the largest amount of structural data ( $>141,000$ deposited structures as of 2 January, 2020 in the research collaboratory for structural bioinformatics (RCSB) database), which dwarfs the number of structures derived from nuclear magnetic resonance (NMR) $(>12,000)$ and cryo-electron microscopy (cryo-EM) $(>4100)$. While X-ray crystallography continues to produce structures at a steady rate, NMR has been gradually declining since 2007 whilst cryo-EM is increasing at an exponential trajectory. This reflects the recent initiation of a paradigm shift due to the rapid development of instrumentation and methodology in cryo-EM ("resolution revolution"). This applies especially to membrane proteins and large macro-molecular complexes where obtaining well diffracting crystals present a severe bottleneck for structure elucidation $[15,16]$ and drug discovery $[17,18]$.

X-ray crystallography is highly successful in producing structures as it has been polished by decades of process optimization: molecular biology and protein engineering allows multi-parallel constructs and expression screening; instrumentation development and automation by robotics allow high-throughput protein purification and crystallization trials; the continuous upgrade of synchrotron facilities and X-ray detectors allow ever smaller crystal to be measured in ever shorter data collection time. Further synchrotron facilities upgrade to fourth generation diffraction-limited storage ring (DLSR) [19] and utilization of broad-bandwidth pink beam [20] will further increase the photon flux and reduce the application gap with X-ray free electron lasers (XFELs). Software allows automation in parallel processing and ligand fitting of many datasets. Better algorithms for refinement and validation of structural models including dealing with low-resolution data. SBDD has thus become very efficient and feasible for many target classes and has become one of the de facto standards in the pharmaceutical industries' armory of drug discovery technologies [21].

Membrane proteins including G-protein-coupled receptors (GPCRs), solute carrier (SLCs) and ligand/voltage-gated ion channels account for $30 \%$ of the human genome [22] but are the targets of more than $50 \%$ of marketed drugs [23]. SBDD has also become amenable for membrane proteins including GPCRs [24-26] following the application of novel techniques in protein engineering (stabilizing mutation [27,28], insertion of fusion protein [29]), purification in lipidic environment (lipid nanodisc [30], styrene maleic acid lipid particle (SMALP) [31] and saposin-lipoprotein nanoparticle (Salipro)) [32] and new crystallization methodologies such as lipidic cubic phase (LCP) [33], bicelle [34] and crystallization in the presence of high concentration of lipid and detergent (HiLiDe) [35]. Together, these techniques overcome the key issues of the lack of hydrophilic surface for crystallization and instability outside their native membrane environment when extracted by detergents. This has led to unprecedented success as structures of almost 70 GPCRs have become available since 2007 and this vast amount of structural data has immensely helped the scientific community to understand GPCRs' regulatory mechanisms [36].

Cryo-EM is already playing a major role in obtaining structural information for large molecular complexes or inherently flexible proteins where obtaining well-diffracting crystals is a daunting challenge. Some major hurdles in preventing the wider application of cryo-EM to SBDD are insufficient instrument time with high voltage $(300 \mathrm{KeV})$ microscope and the data collection (days) and processing time (low throughput) needed for each structure determination. In the future, it is possible that 
more similarly high resolution cryo-EM structures would be obtained using low voltage $(100 \mathrm{KeV})$ microscope [37], which are more widely accessible and cheaper to buy and to maintain. Cryo-EM and X-ray crystallography would likely become complementary rather than competing techniques in the quest for more structural data from challenging systems [38,39]. X-ray crystallography has the current advantage that once a reliable crystal system (reproducible, soakable and diffracting to high enough resolution to allow unambiguous fitting of ligands) is developed, then multiple protein-ligand complex structures could be delivered very rapidly at a timeframe most suited to SBDD during lead optimization. However, for many proteins for example, to develop a reliable crystal system could take months, if not years, of laborious optimization thus driving up time and cost. This is especially critical for proteins which are not yet amenable for cryo-EM due to size limitation $(<100 \mathrm{kDa})$. Technologies that shorten timelines and improve success rates are still needed to keep up with the demand for structural information in drug discovery campaigns. Serial crystallography using XFEL would represent such a technology.

\section{XFEL and Serial Crystallography}

Serial femtosecond crystallography (SFX) capitalizes on the extreme flux generated by XFELs which are $>10^{9}$ (up to $10^{33}$ peak brilliance (photons $/ \mathrm{s} / \mathrm{mm}^{2} / \mathrm{mrad}^{2} / 0.1 \% \mathrm{BW}$ )) higher than synchrotrons. Free electron lasers have existed since the 1970s [40], but the first FEL that operates in the hard X-ray regime did not exist until 2009 when the Linac Coherent Light Source (LCLS) in California began operation [41]. Since then SPring-8 Angstrom Compact Free Electron Laser (SACLA) [42], EuXFEL [43], SwissFEL [44] and PAL-XFEL [45] have also started operation in Japan, Germany, Switzerland and Korea respectively bringing the total number of hard X-ray XFEL facility to five. This still pales in comparison to more than 50 synchrotrons currently in operation (or in construction) around the world (https://lightsources.org/lightsources-of-the-world/). LCLS is currently being upgraded to LCLS-II, which would be 10,000 times brighter and is expected to begin commissioning in fall 2020. The astronomical cost of building such an instrument ( $>1.2$ billion Euro for EuXFEL) continues to be prohibitive with only the Shanghai High Repetition Rate XFEL and Extreme Light Facility (SHINE) in China as the only new XFEL facility currently in construction and is due to begin commissioning in 2025. Similar to EuXFEL and LCLS-II, SHINE will be based on superconducting accelerator technology capable of generating megahertz X-ray pulses (contrary to $<120 \mathrm{~Hz}$ in LCLS, SACLA, SwissFEL, and PAL-XFEL).

Serial crystallography differs in many fundamental aspects to conventional cryo-crystallography and demands innovation in all areas including sample preparation, delivery, data collection and processing. XFELs generate intense $X$-ray pulses containing $\sim 10^{12}$ photons lasting tens of femtosecond (10-15 fs). This allows "diffraction before destruction" [46] and opens new opportunities for structural biology [47-49]. The potential to collect radiation damage-free data from XFELs was early demonstrated for lysozyme [50], photosynthetic reaction center [51] and cytochrome c oxidase [52]. The combination of high flux and sub-micron focus beam $(<1 \mu \mathrm{m} \times 1 \mu \mathrm{m})$ allows microcrystals $\left(<5 \mu \mathrm{m}^{3}\right)$ of angiotensin II receptor [53], $\delta$-opioid receptor [54], CPV17 polyhedrin [55] and melatonin receptor 2 (MT2) [56] to be used for data collection, which otherwise did not provide sufficient diffraction volume at synchrotron. Serial crystallography thus represents the next frontier in X-ray crystallography and has the potential to address the crystallization bottleneck of requiring large, well-diffracting crystals of membrane proteins for SBDD [57-59]. A further unique potential of XFEL is the femtosecond data collection regime, allowing time-resolved dynamic studies at sub-picosecond timescales relevant to many biological processes. This method constructs "experimental molecular movies" that showed the conformational dynamics for bacteriorhodopsin [60], bovine cytochrome c oxidase [61], photoreactive yellow protein [62] and photosystem II [63] upon light excitation.

\section{The Need for Sample Delivery}

Revolutionary technologies come with principal challenges. "Diffraction before destruction" dictates that a single still diffraction snapshot with only partial reflections is obtained per crystal. 
Full reconstruction of diffractions' 3D profile in reciprocal space requires Monte Carlo method of merging from a very large number of recorded diffraction images and reflections [64]. Fresh crystals have to be supplied in a continuous stream until enough partials are collected to compile a full dataset. Successful XFEL data collection then depends on optimal sample delivery. The XFEL instrument repetition rate, sample environment, available sample amount, and the mechanical properties of the crystals have to be considered to choose the most appropriate sample delivery medium and parameter. In an ideal scenario, sample delivery methods for XFEL should:

1. Conserve maximum crystal diffraction quality by minimizing mechanical and chemical stress during sample preparation and data collection.

2. Maximize the signal-to-noise ratio of Bragg peaks by minimizing background scattering from the crystal carrying medium and container.

3. Minimize sample wastage with crystal delivery that synchronizes to the XFEL repetition rate.

4. Allow automation and robust operation (high-throughput) to minimize latent machine time due to sample changing or clogging.

5. Allow homogenous "pump" triggers including rapid mixing with ligands or light permeation for time-resolved pump-probe experiment.

6. Maintain sample stability until "diffraction before destruction".

Sample delivery has become a main area of focus in research and development for serial crystallography. Principally main sample delivery methods have been divided into sample jet (liquid or viscous), fixed-target chip or drop-on-demand [65-67]. Many variables influence the ultimate choice of sample delivery methods (Figure 1), and alternative options exist for many systems. This review summarizes different sample delivery methods and their pros and cons (Table 1) from a user perspective.

Table 1. Comparison of main sample delivery methods pros and cons.

\begin{tabular}{|c|c|c|c|}
\hline Delivery Method & Pros & Cons & $\begin{array}{c}\text { Key } \\
\text { Limitation/Opportunity }\end{array}$ \\
\hline Liquid jet & $\begin{array}{l}\text { Low background } \\
\text { Efficient mixing with ligand } \\
\text { for TR-SFX }\end{array}$ & $\begin{array}{l}\text { High sample consumption } \\
\text { Prone to nozzle clogging } \\
\text { Low throughput sample changing }\end{array}$ & $\begin{array}{l}\text { High data collection } \\
\text { efficiency at } \mathrm{MHz} \text { XFELs }\end{array}$ \\
\hline LCP jet & $\begin{array}{c}\text { Low sample consumption } \\
\text { Protein grown in LCP can be } \\
\text { used directly } \\
\text { Large variety of choice } \\
\text { of matrixes } \\
\text { Can also be used for crystals } \\
\text { in suspension }\end{array}$ & $\begin{array}{c}\text { Higher background } \\
\text { (depends on matrix used) } \\
\text { Some sample manipulation } \\
\text { at harvest } \\
\text { Low throughput sample changing }\end{array}$ & $\begin{array}{l}\text { High throughput sample } \\
\text { changing }\end{array}$ \\
\hline Fixed target chip & $\begin{array}{c}\text { Low sample consumption } \\
\text { In situ crystallization } \\
\text { High throughput sample } \\
\text { changing } \\
\text { Sample preparation and data } \\
\text { collection at cryo-genic } \\
\text { temperatures }\end{array}$ & $\begin{array}{l}\text { Higher background (depends on } \\
\text { support matrix used) } \\
\text { Sample stability needs to be } \\
\text { maintained before and during } \\
\text { data collection } \\
\text { Preferential orientation risk of } \\
\text { certain crystal morphologies } \\
\text { Data collection efficiency limited } \\
\text { by robotic arms }\end{array}$ & $\begin{array}{l}\text { Maximize sample and } \\
\text { data collection efficiency } \\
\text { by crystal pre-location } \\
\text { (difficult to apply for } \\
\text { viscous samples) }\end{array}$ \\
\hline Drop-on-demand & $\begin{array}{l}\text { Low sample consumption } \\
\text { High sample efficiency }\end{array}$ & $\begin{array}{l}\text { More suitable for larger crystals } \\
\text { Higher solvent background } \\
\text { Compatibility with TR-SFX }\end{array}$ & $\begin{array}{l}\text { Cannot be applied to } \\
\text { viscous samples }\end{array}$ \\
\hline
\end{tabular}




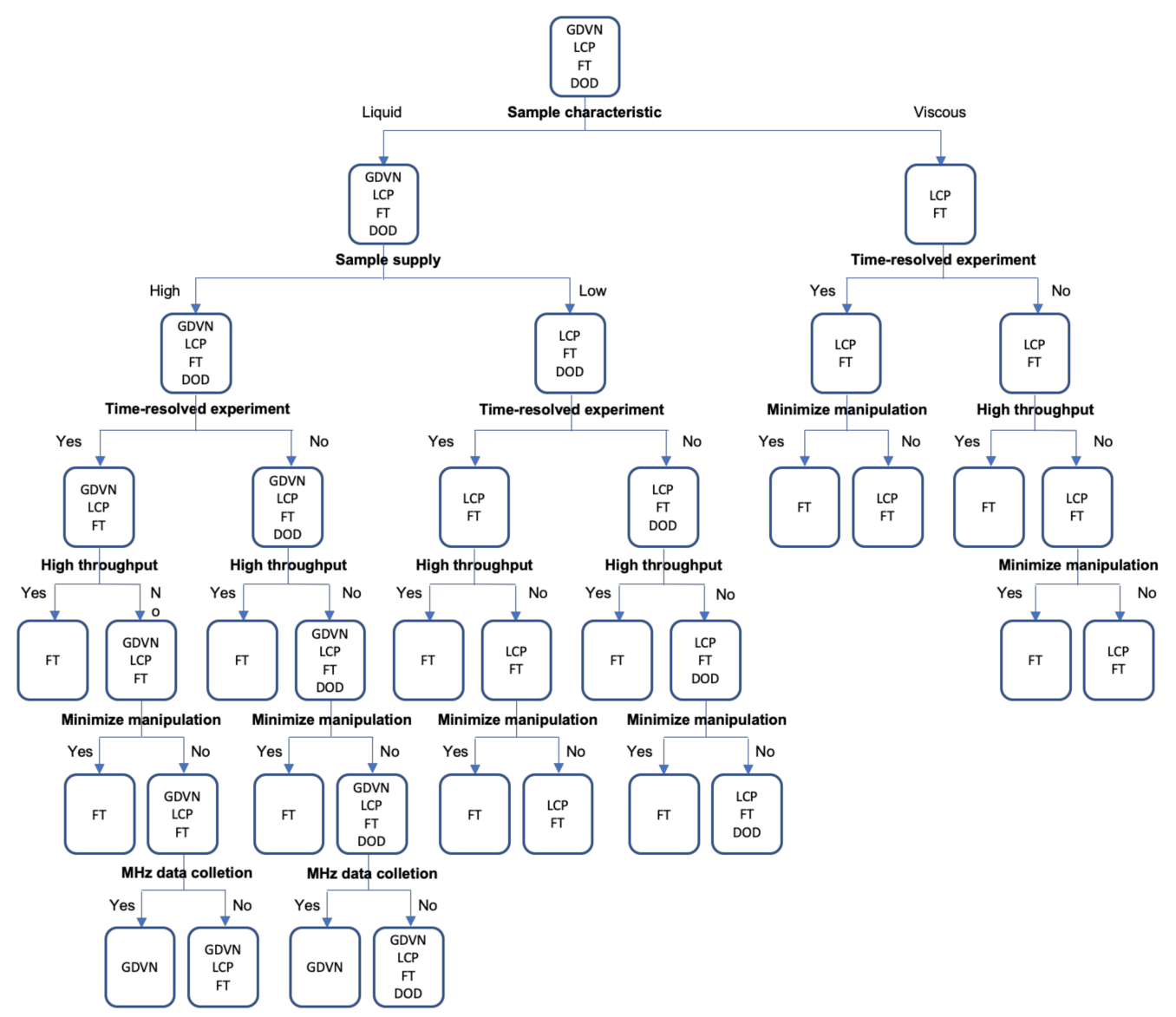

Figure 1. An example of a sample delivery method decision tree. Some major experimental considerations are used here to illustrate options for sample delivery, but likely not including criteria specific to individual sample and experimental requirement. Decisions are suggested based on current knowledge and may not reflect on future development trend. GDVN, gas dynamic virtual nozzle jet; LCP, lipidic cubic phase jet; FT, fixed target support; and DOD, drop-on-demand.

\section{Serial Crystallography Sample Preparation}

Conventional crystallography is synonymous with the need to grow a large single crystal to provide sufficient diffraction volume. Radiation damage limits the useful diffraction lifetime of crystals, with the tolerated dose at room temperature established at 1 MGy [68]. Cryo-crystallography is deployed to mitigate its effects and extend the radiation dose limit to 30 MGy [69], enabling a complete dataset to be collected from a single crystal. This is a delicate balance as larger crystals are more prone to defects (e.g., increased mosaicity) introduced by freezing and time needs to be invested in optimizing cryo-protection protocols. This situation is now changed with serial crystallography as it negates the need for both large crystals and cryo-protection. Crystals of homogenous size give more consistent diffraction pattern between images which is beneficial for data merging. It is also less likely to cause jet clogging as the appropriate capillary diameter can be chosen for jetting if there is little size variation in the crystal population. Microcrystals $(<10 \mu \mathrm{m})$ are preferred in time-resolved dynamics experiment as the small crystal volume allows faster and more homogenous pump-probe trigger by photons or diffusion of small molecules. High density of crystals will maximize the likelihood of an XFEL pulse intersecting with a passing crystal in the stream, hence increasing data collection efficiency. The focus of serial crystallography sample preparation is thus shifted to produce high densities of small, homogenously-sized microcrystals.

Batch crystallization is frequently used to produce high density of microcrystals as it allows precise mapping of the crystallization phase diagram that drives crystal nucleation and growth. It is 
also easier to mass produce microcrystals on the scale needed for serial crystallography compared to vapor diffusion, in which the equilibration kinetic between protein and precipitant varies between crystallization plates and volume of the drops. Another advantage of batch crystallization is that the density of crystals can be adjusted as desired by collecting the sample after low speed centrifugation and resuspension in an appropriate volume of buffer solution. Adaptation into batch crystallization from that used for the production of large singular crystals in vapor diffusion requires some optimization work. This has been demonstrated by rapid titration of the protein into precipitant solution $[70,71]$ or careful mapping of the crystallization phase diagram as shown with ferric uptake transporter $\mathrm{A}$ (FutA) and flavin prenyltransferase UbiX [72]. Conditions from vapor diffusion can also produce high density of microcrystals by controlled evaporation to push the protein into supersaturation [73], multiple rounds of seeding [74], or by direct crushing of macrocrystals using seed beads [74,75]. Sample preparation of crystals grown in LCP (which is in batch) follows a similar principle [76]. However, as LCP is viscous, increasing the crystal density by centrifugation would not be feasible and the crystallization conditions need to be optimized to yield high density of microcrystals. Optimization during scale up in Hamilton syringes, however, may not be very efficient and an alternative well-based approach using normal crystallization trays has been proposed [77]. This also facilitates easier tracking of crystallization progress with microscopic imaging. Seeding has achieved great success for soluble protein and is also feasible for crystals grown in LCP [78]. However, adaptation of a seeding protocol for serial crystallography sample preparation has not yet been reported.

A most interesting development recently has been the use of crystals grown in vivo. Protein nanocrystals have been observed to grown in vivo, whether as an artefact of protein overexpression in the host cell or as part of the viral capsid assembly process $[79,80]$. The use of crystals grown in vivo has the distinct advantage that protein biochemistry is greatly simplified and crystals are preserved in the most pristine state. Crystals grown in vivo also appear to be more uniform in size [81]. The first demonstration of using crystals grown in vivo for XFEL data collection was shown in 2012, when isolated Trypanosoma brucei cathepsin crystals grown in Sf9 insect cells were injected into the XFEL pulses $[81,82]$. This was then followed by other examples including neuraminidiase grown in chinese hamster ovary (CHO) cells [83], Cry3A toxin from Bacillus thuringiensis [84], CPV17 polyhedrin [55], granulin [80], phiX174 viral particle [85] and alcohol oxidase contained inside yeast peroxisomes [86]. In some cases, crystals are first extracted from host cells $[80-82,84,86]$ using filtration or density gradient ultracentrifugation before injection into XFEL pulses while in other experiments host cells are directly injected [84,85], thus further simplifying sample preparation. One comparison of extracted crystals versus direct host cells injection revealed datasets are of comparable quality [84]. The use of crystals grown in vivo for XFEL data collection is an interesting prospect. However, it is limited in scope as this could not be applied to membrane proteins, which express in a single layer lipid bilayer, or to proteins that could not be overexpressed in a host cell.

Serial crystallography experiments require prudent planning. Room temperature data collection provides an additional challenge as crystals could suffer a drop in diffraction quality over long term storage and transport and need to be in their most optimal state before XFEL beamtime. The size, size distribution, density and diffraction quality of crystal needs to be characterized as XFEL beamtime is precious. A wide variety of characterization methods have been reported for this in the literature. Crystal size and density could be investigated by examination under the microscope $[71,72,83]$ or using Dynamic Light Scattering (DLS) [70,87]. UV fluorescence imaging and SONICC (second-order nonlinear imaging of chiral crystals) are used to distinguish salt from protein crystals $[70,71,73]$. Diffraction quality is checked by X-ray powder diffraction at the synchrotron $[71,73,80,86]$, and the result could reveal if crystals have preferred orientation in the liquid stream due to certain crystal morphology [71]. Advanced electron microscopy techniques including scanning electron microscopy (SEM) and transmission electron microcopy (TEM) have also been used to examine size distribution and are typically employed for in vivo grown crystals [73,80-82,84-86]. In many cases, a combination of techniques is used to provide a more complete picture prior to XFEL data collection $[70,71,73,81,86,87]$. 
TEM has been used to simultaneously provide information on crystal size distribution, diffraction quality, and monodispersity $[88,89]$.

\section{Liquid Jet for Crystals Suspended in Solution}

Protein crystals are typically grown in aqueous solution. During XFEL measurements crystals are continuously streamed across the X-ray intersection point in a thin liquid column to keep crystals hydrated and to minimize background contribution. The first serial crystallography measurement at LCLS utilized nanocrystals ( $200 \mathrm{~nm}$ to $2 \mu \mathrm{m}$ in size) of photosystem I that were delivered to X-ray pulses using a gas dynamic virtual nozzle (GDVN) [90]. The GDVN uses a double capillary design [91,92] in which a liquid stream of aqueous crystal suspension is delivered within an inner capillary of 40-100 $\mu \mathrm{m}$ in diameter [93]. Co-axial sheath gas flow (typically helium) in the outer capillary compresses the liquid stream (typically to $5-10 \mu \mathrm{m}$, but potentially to as low as $300 \mathrm{~nm}$ in diameter $[93,94]$ ), thus acting as a virtual nozzle [94]. The gas flow pressure controls the diameter of the liquid stream to suit the sample characteristics (e.g., crystal size), to optimize the signal to noise ratio from solvent background and to ensure stable jet flow [95]. Co-axial gas also prevents ice formation at the nozzle due to evaporative cooling in a vacuum environment [94]. GDVNs are now routinely used to deliver aqueous crystal suspension for XFEL data collection under vacuum or ambient condition [96]. It alleviates the problem of nozzle clogging associated with solid-walled aperture Rayleigh jets when the aperture diameter needs to be smaller than the inner capillary and is thus susceptible to particle clogging [91,93].

Smooth jetting is of critical importance for any XFEL experiment as beamtime is scarce. This is particularly true in time-resolved experiments, where reliable four-dimensional structural data is only meaningful with precise and consistent timing between "pump" trigger and "probe" data collection. Manual flame-polishing of the outer sheath glass capillary end of the GDNV introduces inherent variability of jet speed and flow trajectory between the nozzle and the jet stream [93]. To overcome this challenge and to improve the precision in nozzle microfabrication, ceramic micro-injection molding [95] and high resolution 3D printing using 2-photon polymerization [97] has been used to produce nozzle that delivers reproducible stable jet flow, with the additional advantage of rapid prototyping and testing of different geometric designs. Crystal clogging and settling in low viscosity buffers pose further issues. Crystals of homogenous size are desired to avoid clogging and to obtain more consistent diffraction between images. This has been achieved by pre-filtering $[90,98]$ or sorting using microfluidics techniques [99] to remove larger crystals from the crystal suspension. Crystals settling has been avoided by using an anti-settling device [100] or by increasing the viscosity of the sample with the addition of sucrose [94]. However, care needs to be taken when reagents are added to the sample which could adversely affect crystal quality.

The surface tension of liquid will cause sample to drip out of the nozzle at slow flow rate. GDVN jets are typically run at a flow rate of $10-30 \mu \mathrm{lmin}^{-1}$ at a jet speed of $25-100 \mathrm{~ms}^{-1}$ for stable jetting [96]. While this flow rate is orders of magnitude smaller than a Rayleigh jet $\left(\sim \mathrm{mlmin}^{-1}\right)$ of equivalent diameter, crystals are still replenished much faster than X-ray pulses in XFEL operating at a $<120 \mathrm{~Hz}$ repetition rate, with the consequence that the vast majority of crystals in the liquid stream do not intersect with the XFEL pulses and are wasted. For photosystem I only 1 in 25,000 crystals intersected with the XFEL pulses operating at $30 \mathrm{~Hz}$, with $10 \mathrm{mg}$ of protein consumed to collect 1.85 million indexed images [90]. This poses a particular challenge for difficult-to-express proteins, such as membrane proteins, which require very expensive detergent reagents. Sample consumption thus becomes the major concern for GDVNs. XFELs operating in the MHz range (EuXFEL, LCLS-II, and SHINE) would be more suited to the high flow rate of a GDVN jet, but due to the short spacing ( $220 \mathrm{~ns}$ in EuXFEL) between pulses in a pulse train arising from these superconducting accelerator sources, extra adaptation (e.g., jet diameter, jet speed and interpulse spacing) would be required for optimal data collection [101,102]. It will be interesting to see if the GDVN jet becomes more highly utilized as more beamtime becomes available from XFELs operating at the $\mathrm{MHz}$ range. 
The double-flow focusing nozzle (DFFN) was developed to address some of the concerns on sample consumption [103]. The DFFN employs double co-axial flow where the crystal suspension is focused by an outer sheath of a co-flowing solvent like ethanol. The outer sheath liquid is then focused by gas, as for a GDVN. This helps to focus the crystal suspension to a finer jet $(2-5 \mu \mathrm{m})$, resulting in up to eight-fold reduced sample consumption and further less built up of debris on the nozzle compared to a GDVN [103]. In the Microfluidic Electrokinetic Sample Handling (MESH) injector, a positive electric potential is applied to the sample. The electric potential overcomes the surface tension of the liquid and facilitates microjet formation while running at a much lower flow rate of $0.14-0.31 \mu \mathrm{Lmin}^{-1}$ [104]. MESH requires the presence of glycerol or polyethylene glycol (PEG), reagents commonly present in crystallization, to prolong droplet formation and sample freezing in vaccuo and has the additional benefit of preventing crystals settling in the jet. Using this injector, 14,000 diffraction images were collected using only $140 \mu \mathrm{g}$ of thermolysin, with no sign of crystal damage from the electric field [104]. Later the same group developed the concentric-flow electrokinetic injector (coMESH), in which the inner crystal suspension is shielded with a co-flowing sister liquor similar to the setup with GDVN [105]. This overcomes issue with dehydration and freezing of the sample when injected into vacuum using a MESH injector.

\section{Lipidic Cubic Phase (LCP) Injector for High Viscosity Sample Injection}

Crystallization in LCP is instrumental for the structural determination of membrane proteins, especially GPCRs [106]. Purified protein in detergent micelle is reconstituted into a host lipid (typically monoolein) which mimics the native lipid bilayer for enhanced stability. Addition of a precipitant solution swells the cubic phase, producing an enlarged lattice and a solvent channel diameter conductive to protein diffusion within the lipid and initiating crystal nucleation [106]. Unlike liquid, lipidic cubic phase is viscous and has a toothpaste-like consistency. Consequently, it does not present similar dripping issues when used at slow flow rate. Low jet speed reduces the proportion of unexposed crystal traffic in the stream and is particularly suited to XFELs running below $120 \mathrm{~Hz}$. However, to extrude viscous material much higher pressure is needed. Weierstall et al. devised such an injector to extrude LCP [107]. The LCP injector is connected to a HPLC pump and hydraulics drive a plunger which pushes the LCP through a narrow silica capillary of 50-150 $\mu$ m diameter. This amplifies the pressure up to 10,000 psi [107]. The capillary channel diameter needs to be bigger than the size of crystals to avoid jet clogging, but a smaller diameter is preferred as it reduces sample consumption and background scattering. However, this produces a crystal stream column with a diameter that is substantially bigger than that produced by a GDVN jet, thus giving a higher background. Similar to the GDVN, the LCP injector employs a sheath co-flowing gas (helium or nitrogen) to maintain the downward flow trajectory of extruded LCP. Shorter-chain lipids like monopalmitoolein or 7.9 MAG is usually added to avoid monoolein transitioning from LCP to lamellar $\mathrm{L}_{\mathrm{c}}$ phase due to evaporative cooling in vacuo [107]. A similar device for high viscosity injection is also installed in the diverse application platform for hard X-ray diffraction in SACLA (DAPHNIS) chamber in SACLA [108]. In addition to the LCP jet, this high-viscosity jet in SACLA employs a flowing water system to control the sample temperature and a suction device to maintain the flow of the LCP stream and collect sample waste.

An immediate advantage of the LCP jet is the direct harvesting and loading of crystals grown in LCP, which is often used for the growth of membrane protein crystals. This avoids extra manipulation step that could introduce damage and reduce the diffraction quality of crystals. The LCP jet is run at $1-300 \mathrm{nLmin}^{-1}$ [107] which is at least an order of magnitude slower than a GDVN jet and thus consumes much less sample (typically $<1 \mathrm{mg}$ of protein) especially beneficial to proteins that are difficult to produce. Crucially, the much higher pressure needed to extrude LCP did not seem to adversely affect crystal diffraction quality [107]. To take advantage of this low sample consumption and broaden the applicability to samples not grown or not sufficiently stable in LCP [109], a wide variety of viscous matrixes with broad hydrophobic and hydrophilic compatibility (reviewed in [110]) have been demonstrated for serial crystallography data collection. These includes mineral oil grease [111], 
agarose [112], hyaluronic acid [113], synthetic grease [113], Vaseline [114], nuclear grease ([115], hydroxyethyl cellulose [115], sodium carboxymethyl cellulose [116], pluronic F-127 [116], polyethylene oxide [117], polyacrylamide [118], fat-based shortening [119], dextrin palmitate/paraffin grease [120], and dextrin palmitate/dialkyl tetraphenyl ether grease [120]. To utilize these matrixes crystals grown in batch mode are spun down to remove excess mother liquor before embedding into the matrix by manual mixing either with a spatula or Hamilton syringe. A more gentle method without centrifugation is allowing crystal suspensions to settle at the bottom of Hamilton syringes before excess mother liquor is pushed out from the top [119]. After mixing crystals should be checked under the microscope for signs of damage, either due to chemical incompatibility with the matrix or shear force from mechanical mixing. It has been reported that proteinase $\mathrm{K}$ crystals in dextrin palmitate/paraffin grease could be frozen without affecting crystal diffraction quality [120], hence simplifying sample transport.

Matrixes differ in their ease of preparation, commercial availability and cost and all of these factors need to be considered during sample preparation. Flow rate (between $0.1-2 \mu \mathrm{Lmin}^{-1}$ ) and capillary diameter also needs to be established empirically to ensure stable jet flow and this should be tested, for example, using a high-speed camera [121,122]. The broad chemical variety however allows the screening of a suitable matrix that is compatible with the properties of the crystal samples and their carrier solvent. Hydrophilic matrixes (hyaluronic acid, hydroxyethyl cellulose, sodium carboxymethyl cellulose and agarose) have the additional advantage of having a much lower background scattering comparing to LCP, which has a prominent background at the resolution range of 4-5 the signal-to-noise ratio, which is especially useful during experimental phasing $[114,115,120]$. The LCP jet has proven its potential and it has become the standard jetting method for de novo structure determination at XFEL for GPCR microcrystals $\left(<5 \mu \mathrm{m}^{3}\right)$ [53,54,56,123-125].

\section{Fixed-Target Approach Offers In-Situ Serial Crystallography}

Despite reducing sample consumption in high viscosity medium using the LCP jet, sample delivery using jet methods ultimately rely on the chance occurrence of XFEL pulses intersecting with a passing stream of crystals. This is inefficient as the hit rates typically observed $(<10 \%)$ are far below the $37 \%$ ideal maximum for single diffraction pattern per image as modelled by Poisson statistic $[126,127]$. Alternative methods have been explored in which crystals are deposited onto a solid support matrix before exposure to XFEL pulses. This fixed-target or solid support approach is not dissimilar in root to goniometer-based synchrotron data collection, where multiple crystals harvested in a micromesh or grown in an in situ plate are presented to the X-ray beam. It thus utilizes similar translation stage and robotics for sample changing as deployed in conventional cryo-crystallography. Consequently, material and method optimization can be tested at synchrotron beamlines and subsequently applied in XFEL [128]. Fixed target approaches also offer the possibility of on-chip crystallization (including in LCP [129]) and data collection in situ. This eliminates mechanical stress arising from crystal manipulation and the high-pressure needed to extrude the sample using jet-based methods, and without the issues of nozzle clogging and irregular jet speed that make time-resolved dynamics studies challenging. Crystals can be deposited in a regular array and every XFEL pulse could hit a crystal at pre-defined locations, thus maximizing sample efficiency. Crystals could be frozen as in conventional cryo-crystallography, so serial crystallography data could be collected at cryo-genic temperatures. Freezing also simplifies sample storage and transport. Chips can also be mounted at an angle to the X-ray beam for crystals (especially needles or plates) that suffer preferential orientation on the chip, thus sampling more complete reciprocal space. Unfortunately, the use of a solid support matrix comes also with challenges: mainly the support matrix contributes to additional background scattering especially detrimental to weak Bragg diffraction; the support matrix needs good mechanical stability to withstand the high intensity X-ray pulses; and at ambient temperature crystals could suffer from dehydration during in-situ crystallization, sample loading and data collection. Hence, the support matrix should be resistant to water evaporation. 
Many fixed-target chip designs employ crystalline silicon [130-134] or silicon nitride [126,135-138]. These materials are chosen for their low scattering background, high transmission to X-ray and great precision in microfabrication using photolithography technique. In some designs, crystal suspensions are manually deposited in a silicon frame sandwiched between one or two thin layers of silicon nitride membranes [126,135-137]. While in others either one or both of the silicon nitride membranes are replaced with a thin layer $(8-10 \mu \mathrm{m})$ of polyimide (Kapton) foil [130,136,139] or Mylar film [137]. To further reduce background scattering, alternative materials such as polycarbonate plastic [129], Mylar films [140], single-layer graphene [141], monocrystalline quartz [142] and nylon mesh [143] have also been used and all have reported excellent transmission to X-ray. Use of graphene and quartz gives the additional benefit of negligible permeability to water over prolonged periods. In the case of Mylar films, datasets were collected for lysozyme and oxyhemoglobin A, but significant damage to the chip was observed when tested at SACLA using an unattenuated beam with a photon energy of 7.3 KeV [141].

"Diffraction before destruction" inevitably leaves behind a trail of destruction to an area larger than the beam due to secondary radiation damage events [144] and dissipation of thermal energy, which affects unexposed samples nearby. During data collection the chip needs to be translated at regularly spaced intervals $(30-100 \mu \mathrm{m})[128,140]$ between pulses to avoid samples contaminated with radiation damage from a previous exposure event. This limits sample efficiency if crystals are randomly deposited on a chip and fall in the secondary radiation damage area. Focus is then on maximizing sample efficiency by distributing crystals in pre-defined "boxes" spaced regularly apart. Zarrine-Afsta and coworkers utilized a silicon mesh design in which crystals are deposited in 45-60 $\mu \mathrm{m}$ wells. To facilitate random crystal orientation, wells contain glass beads of varying sizes to introduce different region of hydrophilicity and roughness. These wells are sealed on both sides with polyimide foil to prevent crystal dehydration [130]. Murray and coworkers introduced parallel channels in the silicon nitride membrane and altered the hydrophobic/hydrophilic surface distribution to encourage crystals to preferentially reside in the channel and adopt random orientation [136]. Chips employing microfluidics have also been successfully used to trap crystals in selective location [145], although the material poly(dimethylsiloxane) (PDMS) used to fabricate the devices suffers from strong background scattering [145]. To further reduce background scattering from membrane on both sides, silicon chips with open-well designs have also been developed. These could either contain tapered holes [146,147], micropores $[131,133,134]$ or wells etched into trapezoidal shapes to draw crystals into wells using suction [137] with varying degree of success and hit rate reported. These open-well chip designs have the additional advantage that excess mother liquor can be removed by suction or filter paper to further reduce solvent background [131-134,137,146,147]. Combining with UV spectral mapping to pre-define locations of crystals on the chip, a very high hit rate of $84 \%$ has been observed [137], thus maximizing data collection efficiency.

Unless crystals are completely sealed from the environment, as with in situ crystallization on the chip $[129,134,138,139,141]$, exposure to air during sample loading and data collection causes dehydration and degradation of crystal quality. Paratone-N, a commonly used cryo-protectant with low water permeability, has been used to embed crystals to prevent dehydration during chip loading $[126,128,129]$, but this requires vigorous mixing and may not be compatible with all crystal systems. Humidified air is frequently used to reduce dehydration during sample loading onto the chip $[131,132,134,137,140,147]$ and data collection $[132,133]$. Air introduces some background scatter and humidified helium could be used instead inside the sample chamber [134]. Encouragingly, crystals did not seem to suffer from dehydration when exposed to air in a humidified environment, negating the need for a polyimide or silicon nitride membrane cover [132-134]. Besides reducing background this also allows high-throughput ligand soaking [134] and controlled dehydration experiments directly on the chip [133], which would be especially beneficial for membrane protein crystals given their high solvent content [148]. 


\section{Drop-on-Demand-Potential to Maximize Sample Efficiency}

Maximum sample efficiency is achieved if crystals are delivered intermittently at a frequency perfectly in sync to arriving XFEL pulses. Fixed target chips with crystals pre-loaded into designated locations (wells) address this to some extent, but significant hurdle remains if this goal is to be realized. Acoustic droplet ejection (ADE) utilizes the fact that crystals are usually suspended in liquid solution with low surface tension. In ADE high frequency sound waves are produced by a transducer, which propagates through the liquid medium and ejects a train of droplets at the surface with great accuracy in volume (nanoliter to picoliter), trajectory and frequency [149]. Being non-contact ADE has distinct advantages in liquid handling and has found great application throughout the crystallography pipeline starting from crystallization [150], microseeding [151], and ligand soaking [152-154] to crystal mounting $[155,156]$. Since droplets are ejected at a frequency compatible with the repetition rate of first generation XFEL facilities, ADE has also been utilized as a sample delivery method at both XFEL and synchrotron [157-160]. By altering the transducer's frequency, the volume of ejected droplets can be tuned to accommodate different sizes of crystals from 5 to $800 \mu \mathrm{m}[160,161]$. Ejected droplets carry significant volumes of mother liquor [157], which contributes to more background compared to jet or fixed-target chip [157]. Hence ADE may be more suitable for larger crystals.

For maximal efficiency every ejected droplet should be hit with an XFEL pulse. This requires very high accuracy and precision in the ejection trajectory and timing [157]. Alternatively, ejected droplets could be trapped in pressure node and levitated into mid-air using a reflector $[159,160]$. This maintains the position of the droplet while being probed by X-rays. However, a levitating drop spins at high frequency and requires a high frame rate detector with a low latent readout time to avoid collecting overlapping diffraction patterns in a continuous dataset $[159,160]$. Rapid spinning allows fast sampling of reciprocal space and alleviates issues with sample dehydration, but limits the dose that could be deposited per frame [159]. As the spinning trajectories in all XYZ orientations also need to be taken into account, data have to be processed as still images using software developed for serial crystallography $[159,160]$. This problem would be avoided with the single shot approach used in XFEL. Combining ADE with the fixed-target approach, droplets have also been ejected onto a solid support surface like polyimide tape [158], silicon nitride chip [162], and mesh [156]. Ejection onto polyimide tape broadens the approach, as it allows simultaneous spectroscopy measurement of the sample and time-resolved pump probe study at a longer timescale [158].

Sound waves have not been the only method used for droplet ejection in serial crystallography. A train of ejected droplets has been created by applying pulsed electric voltage [161] to a piezo-driven nozzle with similar spatial and temporal precision as demonstrated with lysozyme crystals [161]. Another approach utilized the immiscibility between water and oil. In this "water-in-oil" approach, the crystal stream is mixed into oil at regular interval using a 3D-printed droplet generator [163]. The resulting oil stream, with crystals encapsulated in distinct oil droplets, is then ejected into the XFEL pulse using a GDVN nozzle [163]. Smaller nanoliter-sized droplets have also been generated from microfluidic devices using surface acoustic waves (SAW) [164]. The same technique has been used to deliver femtoliter-sized droplets for cryo-EM grid preparation [165]. Drop-on-demand therefore has great potentials in rivalling jet-based methods in cutting sample consumption.

\section{Other Sample Delivery Methods}

Other implementations have also demonstrated their proof-of-concepts as viable sample delivery methods for serial crystallography. In the crystal extractor [166], crystals were extracted onto a mesh or thin-film substrate and carried into the path of the X-ray beam. Diffraction data is collected by raster scanning of the substrate, followed by stringent data processing criteria to avoid including diffraction images from crystals contaminated from a previous exposure. This process is repeated by dipping the substrate back into the crystal suspension until no more diffraction data could be recorded, indicating that the crystal supply has been exhausted. As crystals are sealed in a container in their native mother liquor solution, the crystal extractor has been shown to be suitable for polyketides synthases crystals, 
which are sensitive to mechanical stress and enabled high resolution structural data to be collected at room temperature [166]. As crystal diffraction volume decreases the detrimental effect of background contribution increases. In the aerosol injector, aerosol of granulovirus nanocrystals $\left(<1 \mu \mathrm{m}^{3}\right)$ was generated in a nebulization chamber after injection from a GDVN jet [167]. Aerosolization reduces a substantial volume of carrying solvent from the crystal and diffraction data were then collected from the aerosolized nanocrystals. Due to the size of the aerosolized droplet, the background was substantially (200-fold) less than that observed from the liquid jet [167]. However, the aerosolization process is detrimental to crystals sensitive to mechanical stress. Moreover, the very low hit rate $(0.006 \%$ and $0.83 \%)[167,168]$ observed puts significant hurdles to the wider application of the aerosol injector.

Crystals deposited on a chip could also be extracted and injected into the X-ray beam using far-infrared laser [169]. This laser ablation process preserves the diffraction quality of fluoroacetate dehalogenase crystals, with the advantage that the ablation rate could be tuned in sync to even match higher XFEL repetition rates $(>1 \mathrm{kHz})$ [169]. Laser ablation thus represents another variation of the drop-on-demand technology in minimizing sample consumption. Microfluidic devices [170] and crystals-in-capillary $[171,172]$ have also been applied for sample delivery using synchrotron radiation. The advantage of the latter lies in its simplicity, as crystals could be embedded in agarose or gelatin medium, hence reducing the flow rate $(0.1 \mu \mathrm{L} / \mathrm{min})$ (and sample consumption) to that used for the LCP jet but without the need for jet flow optimization before commencing data collection as required for both the liquid and LCP jet. However, the quartz or silica capillary has not yet been tested as to whether it can withstand intense XFEL pulses [171,172]. Contrary to jet or fixed-target based methods, these alternative sample delivery techniques have not yet been widely-utilized.

\section{Injector Setup for Time-Resolved Experiment}

Time-resolved crystallography would appear to be an oxymoron, given that an X-ray structure represents a conformational static snapshot. Protein conformation is a dynamic continuum and in order to conceive molecular function, one needs to perceive molecular motion. Time-resolved crystallography has a long history before serial crystallography [173]. Structures are solved with proteins "freeze-trapped" in discrete conformations, where each corresponds to a different stage (time) of the structural transformation. A recent example is $\beta$-lactamase, where structures of the apo, substrate acylation and deacylation states were used to illustrate the time-resolved structural mechanism of $\beta$-lactam hydrolysis [174]. These structures are then choreographed and morphed into a molecular movie with temporal "resolution" (analogous to frame rate) dependent on how many transition state conformations could be trapped. In time-resolved serial femtosecond crystallography (TR-SFX) freeze-trapping is not employed, but a biochemical process is triggered in the crystal and after a time delay, probed with X-ray to determine the structure at different time points. Time resolution is then defined by how fast diffraction data could be collected and the duration of the trigger relative to the speed of the formation of structural intermediates. The duration of XFEL pulses and ultra-fast pump laser has made this time resolution available from a few picoseconds to hundreds of femtoseconds [175] which allows ultra-fast biochemical reaction to be studied [176,177]. Methodology developed for TR-SFX has since been transplanted to synchrotrons for TR experiments that proceeds at slower microto milli-second timescales $[114,117,178,179]$.

TR-SFX experiments have been performed for photosystem I-Ferredoxin [180], photosystem II [63,181], photoactive yellow protein [175,182], fluorescent protein rsEGFP2 [183] and bacteriorhodopsin [60,184]. A common feature of these proteins is the presence of a chromophore, which triggers a conformational change upon light activation at specific wavelengths. Light-activated photoswitching is the most commonly used pump trigger in TR-SFX as powerful, ultra-fast nanosecond to femtosecond lasers with tunable wavelengths are available that suit biochemical reactions that occur within these time regime. Optical pump-probe is not only limited to systems with intrinsic chromophore, but also where photons could be used to trigger photolysis $[61,146,185]$ or release caged substrate [122]. The sophistication of TR-SFX requires consistent time delay between pump and probe and so detailed planning and 
precise data acquisition are absolutely essential. Spectroscopy is used to characterize the timescale of structural change in crystals after pump triggering $[60,61,186]$. Laser power and wavelength needs to be established empirically to ensure homogenous penetration and excitation efficiency, while considering the quantum yield of the chromophores $[187,188]$, with photoexcitation yields of around $10 \%$ reported for some systems $[175,184]$. Timing-tools $[189,190]$ monitor the precise temporal resolution between pump and probe for each passing crystal. In a related theme, consistent jet speed is also essential and this could be characterized using a high-speed camera [121,122]. We anticipate that more TR-SFX experiments will be attempted using a more sophisticated pump trigger, such as temperature shifts [191] or $\mathrm{pH}$ jumps using caged proton (Ortho-nitrobenzaldehyde [192]).

TR-SFX puts huge demand on sample consumption, as multiple datasets covering a broad range of time delays are needed to create a molecular movie. For bacteriorhodopsin, in order to collect 13 timepoints, a total of $4 \mathrm{~mL}$ of LCP crystal suspension was required [60], or $1 \mathrm{~mL}$ per $12 \mathrm{~h}$ shift as reported by another group [184]. In another example, $0.3-1 \mathrm{~g}$ of protein was consumed to collect a single timepoint for photoactive yellow protein [182]. It suffices to say that with currently available sample delivery systems, TR-SFX is limited to systems where protein can be produced in quantities of tens to hundreds of milligram, with crystals that diffract to reasonably high resolution in order to observe small structural changes. These requirements put many targets of interest, like difficult to produce membrane proteins, out of reach. Both sample consumption and delivery thus remains major areas of improvement for the feasibility of TR-SFX. Both GDVN and LCP jets have frequently been used for sample delivery for TR-SFX [60,175,181,184,185]. For pump triggering, laser light with pulse energies of $4-20 \mu \mathrm{J}$ is focused onto upstream crystals, with frequencies $(10-30 \mathrm{~Hz})$ lower than that of XFEL pulses resulting in the intermittent collection of "light" and "dark" datasets. Inaccuracy in laser timing (jitters) needs to be corrected with subsequent data analysis and careful binning of images using their time-stamp signature [184]. More homogenous excitation is achieved with more ingenious illumination geometry, such as splitting and refocusing the beam at the sample in two directions $[60,61,122]$ or using double optical-pulses [63].

Inherently, not all biological processes can be triggered by photons. Enzyme-substrate interactions and receptors recognition of their cognate ligands are driven by diffusion of ligands into the binding pocket. Complexities of TR-SFX experiment of such systems arise from the difficulty in synchronizing homogenous and rapid mixing of ligands into crystals to initiate a biochemical reaction. Time resolution is then dictated by the rate of diffusion ( $1 \mathrm{~ms}$ for a $3 \times 4 \times 5 \mu \mathrm{m}^{3}$ crystal, [193]), which needs to be much faster than the rate of catalytic turnover or formation of transient intermediates, and this could be influenced further by the crystal packing environment. For most enzymes, this typically requires sub- $\mu$ s time resolution [193]. Use of caged substrates [122] could bypass the need for rapid diffusion by bringing the substrate at close vicinity, but this requires sophisticated chemistry and may not be applicable to many ligands. TR-SFX experiments using diffusion of a substrate as a pump trigger is usually based on a "mix-and-inject" approach [193-198], in which a substrate is rapidly mixed into crystal suspension to initiate a reaction before delivery into XFEL pulses after a time delay. This requires a different jet set up for sample delivery. Based on the DFFN, a mixing jet was designed in which reactant in the outer-coaxial flow is rapidly mixed into crystal suspension as it is focused into a $\mu \mathrm{m}$-thin jet, with reaction time controlled by the distance between the focusing region and the nozzle tip and its distance to the XFEL pulse [194]. Occupancy in the crystal could then be optimized by varying the concentration of the reactant. The utility of this jet was demonstrated with $\beta$-lactamase $\mathrm{BlaC}$, in which $\mu \mathrm{m}$-sized crystals $\left(<10 \mu \mathrm{m}^{3}\right)$ were mixed with very high concentration $(200-300 \mathrm{mM})$ of ceftriaxone to study the catalytic mechanism at $30 \mathrm{~ms}$ to $2 \mathrm{~s}$ time resolution [197]. In another design crystal slurry of RNA riboswitch and ligands were connected to separate HPLC pumps and mixed at a T-junction reservoir with $10 \mathrm{~s}$ mixing delay, before delivery using a GDVN jet [196]. An even longer time delay (50 s) was demonstrated by mixing and depositing lysozyme/chitotriose mixture on a rolling polyimide tape [195], but this design may only be suitable to reaction on a longer (second) timeframe. 3D printing using a two photons-stereolithography technique was used to prototype a microfluidic 
mixer nozzle to encourage more efficient mixing while jetting at very high speed $\left(160 \mathrm{~ms}^{-1}\right)$ [199]. Overall, the "mix-and-inject" approach for time-resolved studies favor longer time frames.

Fixed-target chips offer the potential to reduce sample consumption which would be particularly valuable in TR-SFX experiment when both sample and ligand are scarce. Mueller and coworkers have shown this using myoglobin crystals on a silicon crystal fixed-target support and demonstrated ultra-fast (200 fs) time-resolved data could be collected using a "difference intensity" approach with "light" and "dark" data collected from the same crystal [146]. The fixed-target approach has also been combined with a piezo-driven droplet injector to dispense picolitre droplets of ligand to crystals on a chip with $\mu$ s to s time delay [200]. To investigate the radiation damage mechanism lysozyme crystals sandwiched between silicon nitride membranes were pumped and multi-probed with X-rays with a series of 19-213 fs time delay [201].

\section{Sample Delivery Present and Future}

Serial crystallography at XFEL represents the next frontier in X-ray crystallography. The ability to extract radiation damage-free structural data is providing a revolutionary advantage for crystals which otherwise do not have sufficient diffraction power at synchrotron. For membrane proteins it is common that tens or even hundreds of datasets needed to be collected and merged to provide a complete dataset using synchrotron radiation [202-205]. This tedious procedure can be improved by in situ data collection using the whole crystallization drop [206] and automated crystal harvesting and data collection pipeline $[207,208]$. This helps to increase throughput and avoids the need to harvest and diffraction screen hundreds of single-mounted crystals. The goal of an X-ray structure is to reveal the structural mechanism of a protein's biological function and ligand recognition at conditions that are close to being physiologically relevant. Serial crystallography data collection at room temperature hence provides a more realistic conformational snapshot and could reveal conformational flexibility/heterogeneity of protein, ligand, and water structures that were otherwise hidden in a cryo structure [191,209-212]. This increases the information content of structural data and helps to better understand protein function and mode of ligand recognition with benefits for structure-based drug design. The capability to extract high resolution data from smaller crystals is another unique selling point for XFEL. Exploding jet [213] or damage to support matrixes [141,201] due to the intense XFEL pulse however means beam attenuation is sometimes necessary during data collection. This limits the flux potential of XFEL and the highest resolution data that could be achieved from a given sample. Research in more robust sample delivery method that can fully utilize the XFEL flux is thus highly desired.

Sample delivery is the grand challenge in serial crystallography, and the scientific community has duly risen to the challenge and presented multiple sample delivery systems with different pros and cons. Reducing sample consumption and maximizing data collection efficiency will be key if serial crystallography is to become a routine method for X-ray structure determination of new protein targets, particularly when XFEL beamtime is still exceedingly difficult and costly to obtain. The LCP jet has lower sample consumption comparing to liquid jet and is particularly more suited for crystals already grown in viscous matrix like LCP. The slower flow rate also better matches the repetition rate of first generation XFEL sources. Chemical incompatibility and extra background scatter from the viscous matrix could be overcome by testing a variety of matrixes. Crystal damage due to sheer force of mixing or chemical incompatibility with the matrix during harvest and loading remains a potential attrition source that should not be overlooked. This contributed to the poor quality of diffraction data obtained for hemagglutinin microcrystal when mixed into agarose [143]. Extra care therefore needs to be taken when handling crystals with needle or plate-like morphology which would be more susceptible to mechanical damage when using the LCP jet. The use of a three-way syringe coupler [121] would help to achieve faster and more homogenous mixing and thus reducing the time crystals suffer from shear force. This also gives the additional benefit of more consistent hit rate during data collection [184]. In principle, mechanical stress would also be minimized, or even avoided, if fixed-target chips are used 
especially when proteins are crystallized and data collected in-situ. This principle was demonstrated recently for CCR2 [214], where the use of in situ crystallization and data collection bypassed the issue of crystal sensitivity to mechanical stress and resulted in better quality data. The major drawback for fixed-target chips, as discussed previously, is the additional background contribution from the support matrix and their mechanical stability when subjected to intense $X$-ray, with sample consumption not necessarily lower than that of jet-based methods. Pre-location of crystals in defined positions on the chip could, in theory, address this issue, but there remains practical challenges as to how this is achieved, especially with samples prepared in viscous matrixes. The same issue applies to drop-on-demand sample delivery methods, where they have shown great promise in reducing sample consumption, but significant technical challenges exist if this technology is to be applied to samples prepared in viscous matrixes.

Sample consumption aside it is clear that all injection methods are capable of delivering great quality diffraction data at high hit rate. Systematic comparison of data quality across different sample delivery methods are scarce, but in one study it was demonstrated with phycocyanin crystals that very similar data judging from standard data quality matrixes (resolution, $\mathrm{I} / \sigma \mathrm{I}, \mathrm{CC}_{1 / 2}$, and $\mathrm{R}_{\text {split }}$ ) could be obtained from both the GDVN and LCP jet using the same experimental setup, with $30 \mathrm{mg}$ of protein consumed for the GDVN versus $0.1 \mathrm{mg}$ for the LCP jet [109]). A similar observation was concluded in another study where crystals of fluorescent protein Skylan-NS in the "on" state were delivered using droplet-on-demand and LCP injector at SACLA [215], with no significant differences in limiting resolution. The authors also collected data of similar quality of Skylan-NS crystals in the "off" state delivered using the droplet-on-demand and the GDVN jet, although datasets were collected at different XFEL facilities (SACLA and LCLS). This reflects the continual difficulties in carrying out a systematic comparison as different XFEL facilities have different beam parameters, sample environments and detector setups. In addition, datasets size needs to be very similar in order to ensure that they are at the same stage of data convergence before data quality can be fairly compared.

During any structure-based drug discovery campaign iterative rounds of protein-ligand structure elucidation are required during lead-optimization. Rapid data collection and sample changing are thus crucial to the collection of multiple ligand complex datasets. To further realize the potential of XFEL, sample delivery for serial crystallography needs to emulate the high-throughput setup already honed for conventional cryo-crystallography. Jet-based sample delivery methods present severe hurdles to this, as only one sample can be investigated per loading and each sample changing still incurs a significant time penalty during a beamtime run. Ligand soaking into crystals in LCP has been demonstrated [216], proving that LCP retains the water channel structure which allows the efficient diffusion of small molecules and opens up the possibility of soaking experiments for samples prepared for the LCP jet. To increase throughput and collect multiple ligand complex datasets for $\beta 2$ adrenergic receptor at LCLS and SACLA, protein was purified in the presence of either timolol or alprenolol and replaced with another ligand of equal or higher affinity during crystallization in LCP [59]. SFX data were then collected for each receptor/ligand complex per loading run, with data collection times between 0.5 to $3 \mathrm{~h}$, depending on hit rate, XFEL repetition rate, indexing rate and the degree of data convergence (typically $>10,000$ indexed images) required for the purpose of the experiment [59]. A similar study was performed for thermolysin [211], where crystals were first soaked with different ligands in batch before mixing into viscous medium for data collection using the LCP jet. Therefore to further boost data collection efficiency and minimize downtime due to sample changing, adaptation of the jet or the experimental hutch design to allow quick sample changing or simultaneous loading of multiple samples per jet loading run will be required.

Logically fixed-target chips would seem to be most suitable for high-throughput serial crystallography at XFEL, as they can utilize similar robotics in synchrotron beamlines for rapid sample changing. Multiple samples could be prepared in advance and loaded into sample changing robots, so no hutch re-entry would be required for an extended data collection run. Crystal dehydration risk upon storage at room temperature would need to be considered and could be eliminated if samples are frozen for data 
collection at cryo-genic temperature. To demonstrate this principle, microcrystals of multiple enzymess including Dye-type peroxidase Aa (DtpAa), Dehaloperoxidase B (DHP), copper nitrite reductase (AcNiR), were soaked with ligands and loaded onto fixed-target chips for SFX data collection [217]. Data collection took on average 14 mins per chip and complete datasets could be collected using 2-4 chips and a total of 1.35-6 mg of protein. Sample consumption aside this translated to $0.5-1 \mathrm{~h}$ XFEL beamtime per complex structure, an entirely reasonable throughput. Crucially, in this study it was also demonstrated that by progressively trimming the size of dataset, less than 1000 indexed images were enough to unambiguously determine the ligand binding mode [217]. This shows the potential for further increase of throughput by reducing the data collection time required for each protein-ligand dataset.

\section{Conclusions}

The last decade has seen sample delivery as one of the key areas of research and development for serial crystallography in XFEL. Great strides have been made in all key aspects of sample delivery aiming for reduced sample consumption, increased compatibility with samples grown in different chemical environments, preserved sample quality, maximized data collection efficiency, minimized background noise, and facilitation of time-resolved pump probe experiments. Continual improvement and innovation from the serial crystallography community in sample delivery methods is expected and will further opens up the technology to a wider scientific community and wider variety of biological samples. With more second generation XFEL facilities coming into operation, it will be interesting to see how current sample delivery methods would be adapted to utilize MHz XFEL pulses. As is often quoted with XFEL: the future of serial crystallography is bright.

Author Contributions: I confirm I am the sole contributor to this manuscript.

Funding: I am a fulltime employee of leadXpro AG. No public funding is involved in this manuscript.

Acknowledgments: I thank Michael Hennig for the critical reading and comment of the manuscript. I thank Jennifer Booker for the final proofreading of the manuscript.

Conflicts of Interest: The author declares no conflict of interest.

\section{References}

1. DiMasi, J.A.; Grabowski, H.G.; Hansen, R.W. Innovation in the pharmaceutical industry: New estimates of R\&D costs. J. Health Econ. 2016, 47, 20-33.

2. Wong, C.H.; Siah, K.W.; Lo, A.W. Estimation of clinical trial success rates and related parameters. Biostatistic 2019, 20, 273-286. [CrossRef]

3. Scott, D.E.; Coyne, A.G.; Hudson, S.A.; Abell, C. Fragment-Based Approaches in Drug Discovery and Chemical Biology. Biochemistry 2012, 51, 4990-5003. [CrossRef] [PubMed]

4. Kunig, V.; Potowski, M.; Gohla, A.; Brunschweiger, A. DNA-encoded libraries-An efficient small molecule discovery technology for the biomedical sciences. Biol. Chem. 2018, 399, 691-710. [CrossRef] [PubMed]

5. Favalli, N.; Basi, G.; Scheuermann, J.; Neri, D. DNA-encoded chemical libraries - achievements and remaining challenges. FEBS Lett. 2018, 592, 2168-2180. [CrossRef] [PubMed]

6. Tsai, J.; Lee, J.T.; Wang, W.; Zhang, J.; Cho, H.; Mamo, S.; Bremer, R.; Fillette, S.; Kong, J.; Haass, N.K.; et al. Discovery of a selective inhibitor of oncogenic B-Raf kinase with potent antimelanoma activity. Proc. Natl. Acad. Sci. USA 2008, 8, 3041-3046. [CrossRef]

7. Harris, P.A.; Berger, S.B.; Jeong, J.U.; Nagilla, R.; Bandyopadhyay, D.; Campobasso, N.; Capriotti, C.A.; Cox, J.A.; Dare, L.; Dong, X.; et al. Discovery of a First-in-Class Receptor Interacting Protein 1 (RIP1) Kinase Specific Clinical Candidate (GSK2982772) for the Treatment of Inflammatory Diseases. J. Med. Chem. 2017, 60, 1247-1261. [CrossRef]

8. Smith, G.M.; Alexander, R.S.; Christianson, D.W.; McKeever, B.M.; Ponticello, G.S.; Springer, J.P.; Randall, W.C.; Baldwin, J.J.; Habecker, C.N. Positions of His-64 and a bound water in human carbonic anhydrase II upon binding three structurally related inhibitors. Protein Sci. 1994, 3, 118-125. [CrossRef] 
9. Navia, M.A.; Fitzgerald, P.M.D.; Mckeever, B.M.; Leu, C.; Heimbach, J.C.; Herber, W.K.; Sigal, I.S.; Darke, P.L.; Springer, J.P. Three-dimensional structure of aspartyl protease from human immunodeficiency virus HIV-1. Nature 1989, 337, 615-620. [CrossRef]

10. von Itzstein, M.; Wu, W.Y.; Kok, G.B.; Pegg, M.S.; Dyason, J.C.; Jin, B.; Van Phan, T.; Smythe, M.L.; White, H.F.; Oliver, S.W.; et al. Rational design of potent sialidase-based inhibitors of influenza virus replication. Nature 1993, 363, 418-423. [CrossRef]

11. Batool, M.; Ahmad, B.; Choi, S. A Structure-Based Drug Discovery Paradigm. Int. J. Mol. Sci. 2019, $20,2783$. [CrossRef]

12. Wang, X.; Song, K.; Li, L.; Chen, L. Structure-Based Drug Design Strategies and Challenges. Curr. Top. Med. Chem. 2018, 18, 12. [CrossRef] [PubMed]

13. Manjasetty, B.A.; Büssow, K.; Panjikar, S.; Turnbull, A.P. Current methods in structural proteomics and its applications in biological sciences. Biotech 2012, 2, 89-113. [CrossRef]

14. Leelananda, S.P.; Lindert, S. Computational methods in drug discovery. Beilstein J. Org. Chem. 2016, 12, 2694-2718. [CrossRef]

15. Cheng, Y. Membrane protein structural biology in the era of single particle cryo-EM. Curr. Opin. Struct. Biol. 2018, 52, 58-63. [CrossRef] [PubMed]

16. Bai, X.C.; McMullan, G.; Scheres, S.H.W. How cryo-EM is revolutionizing structural biology. Trends Biochem. Sci. 2015, 40, 49-57. [CrossRef]

17. Ceska, T.; Chung, C.W.; Cooke, R.; Phillips, C.; Williams, P.A. Cryo-EM in drug discovery. Biochem. Soc. Trans. 2019, 47, 281-293. [CrossRef]

18. Renaud, J.P.; Chari, A.; Ciferri, C.; Liu, W.T.; Rémigy, H.W.; Stark, H.; Wiesmann, C. Cryo-EM in drug discovery: Achievements, limitations and prospects. Nat. Rev. Drug. Discov. 2018, 17, 471-492. [CrossRef]

19. Eriksson, M.; van der Veen, J.F.; Quitmann, C. Diffraction-limited storage rings-A window to the science of tomorrow. J. Synchrotron Rad. 2014, 21, 837-842. [CrossRef]

20. Meents, A.; Wiedorn, M.O.; Srajer, V.; Henning, R.; Sarrou, I.; Bergtholdt, J.; Barthelmess, M.; Reinke, P.Y.A.; Dierksmeyer, D.; Tolstikova, A.; et al. Pink-beam serial crystallography. Nat. Commun. 2017, 8, 1281. [CrossRef]

21. Brown, D.G.; Boström, J. Where Do Recent Small Molecule Clinical Development Candidates Come From? J. Med. Chem. 2018, 61, 9442-9468. [CrossRef] [PubMed]

22. Markus, S.A.; Nordström, K.J.V.; Fredriksson, R.; Schiöth, H.B. Mapping the human membrane proteome: A majority of the human membrane proteins can be classified according to function and evolutionary origin. BMC Biol. 2009, 7, 50.

23. Overington, J.P.; Al-Lazikani, B.; Hopkins, A.L. How many drug targets are there? Nat. Rev. Drug Discov. 2006, 5, 993-996. [CrossRef] [PubMed]

24. Congreve, M.; Dias, J.M.; Marshall, F.H. Structure-based drug design for G protein-coupled receptors. Prog. Med. Chem. 2014, 53, 1-63.

25. Congreve, M.; Oswald, C.; Marshall, F.H. Applying Structure-Based Drug Design Approaches to Allosteric Modulators of GPCRs. Trends Pharmacol. Sci. 2017, 38, 837-847. [CrossRef]

26. Lee, Y.; Basith, S.; Choi, S. Recent Advances in Structure-Based Drug Design Targeting Class A G Protein-Coupled Receptors Utilizing Crystal Structures and Computational Simulations. J. Med. Chem. 2018, 61, 1-46. [CrossRef]

27. Serrano-Vega, M.J.; Magnani, F.; Shibata, Y.; Tate, C.G. Conformational thermostabilization of the beta1-adrenergic receptor in a detergent-resistant form. Proc. Natl. Acad. Sci. USA 2008, 105, 877-882. [CrossRef]

28. Scott, D.J.; Kummer, L.; Tremmel, D.; Plückthun, A. Stabilizing membrane proteins through protein engineering. Curr. Opin. Chem. Biol. 2013, 17, 427-435. [CrossRef]

29. Chun, E.; Thompson, A.A.; Liu, W.; Roth, C.B.; Griffith, M.T.; Katritch, V.; Kunken, J.; Xu, F.; Cherezov, V.; Hanson, M.A.; et al. Fusion partner toolchest for the stabilization and crystallization of $G$ protein-coupled receptors. Structure 2012, 20, 967-976. [CrossRef]

30. Bayburt, T.H.; Grinkova, Y.V.; Sligar, S.G. Self-assembly of discoidal phospholipid bilayer nanoparticles with membrane scaffold proteins. Nano Lett. 2002, 2, 853-856. [CrossRef]

31. Knowles, T.J.; Finka, R.; Smith, C.; Lin, Y.P.; Dafforn, T.; Overduin, M. Membrane proteins solubilized intact in lipid containing nanoparticles bounded by styrene maleic acid copolymer. J. Am. Chem. Soc. 2009, 131, 7484-7485. [PubMed] 
32. Frauenfeld, J.; Löving, R.; Armache, J.P.; Sonnen, A.F.; Guettou, F.; Moberg, P.; Zhu, L.; Jegerschöld, C.; Flayhan, A.; Briggs, J.A.; et al. A saposin-lipoprotein nanoparticle system for membrane proteins. Nat. Methods 2016, 13, 345-351. [CrossRef] [PubMed]

33. Caffrey, M.; Porter, C. Crystallizing membrane proteins for structure determination using lipidic mesophases. J. Vis. Exp. 2010, 3, 2-6. [CrossRef] [PubMed]

34. Faham, S.; Boie, J.U. Bicelle crystallization: A new method for crystallizing membrane proteins yields a monomeric bacteriorhodopsin Structure. J. Mol. Biol. 2002, 316, 1-6. [CrossRef] [PubMed]

35. Gourdon, P.; Andersen, J.L.; Hein, K.L.; Bublitz, M.; Pedersen, B.P.; Liu, X.; Yatime, L.; Nyblom, M.; Nielsen, T.T.; Olesen, C.; et al. HiLiDe-Systematic Approach to Membrane Protein Crystallization in Lipid and Detergent. Cryst. Growth Des. 2011, 11, 2098-2106. [CrossRef]

36. Pándy-Szekeres, G.; Munk, C.; Tsonkov, T.M.; Mordalski, S.; Harpsøe, K.; Hauser, A.S.; Bojarski, A.J.; Gloriam, D.E. GPCRdb in 2018: Adding GPCR structure models and ligands. Nucleic Acids Res. 2018, 46, D440-D446. [CrossRef]

37. Naydenova, K.; McMullan, G.; Peet, M.J.; Lee, Y.; Edwards, P.C.; Chen, S.; Leahy, E.; Scotcher, S.; Henderson, R.; Russo, C.J. CryoEM at 100 keV: A demonstration and prospects. IUCrJ 2019, 6, 1086-1098. [CrossRef]

38. Vénien-Bryan, C.; Li, Z.; Vuillard, L.; Boutin, J.A. Cryo-electron microscopy and X-ray crystallography: Complementary approaches to structural biology and drug discovery. Acta Crystallogr. F Struct. Biol. Commun. 2017, 73, 174-183. [CrossRef]

39. Shoemaker, S.C.; Ando, N. X-rays in the Cryo-Electron Microscopy Era: Structural Biology's Dynamic Future. Biochemistry 2018, 57, 277-285. [CrossRef]

40. Pellegrini, C. The history of X-ray free-electron lasers. Eur. Phys. J. H. 2012, 37, 659-708. [CrossRef]

41. White, W.; Robert, A.; Dunne, M. The Linac Coherent Light Source. J. Synchrotron Rad. 2015, 22, 472-476. [CrossRef]

42. Yabashi, M.; Tanak, H.; Ishikawa, T. Overview of the SACLA facility. J. Synchrotron Rad. 2015, 22, 477-484. [CrossRef]

43. Tschentscher, T.; Bressler, C.; Grünert, J.; Madsen, A.; Mancuso, A.P.; Meyer, M.; Scherz, A.; Sinn, H.; Zastrau, U. Photon beam transport and scientific instruments at the european XFEL. Appl. Sci. 2017, 7, 592. [CrossRef]

44. Milne, C.J.; Schietinger, T.; Alba, M.; Alarcon, A.; Alex, J.; Anghei, A.; Arsov, V.; Beard, C.; Beaud, P.; Bettoni, S.; et al. SwissFEL: The Swiss X-ray free electron laser. Appl. Sci. 2017, 7, 720. [CrossRef]

45. Ko, I.S.; Kang, H.S.; Heo, H.; Kim, C.; Kim, G.; Min, C.K.; Yang, H.; Baek, S.Y.; Choi, H.J.; Mun, G.; et al. Construction and commissioning of PAL-XFEL facility. Appl. Sci. 2017, 7, 479. [CrossRef]

46. Neutze, R.; Wouts, R.; van der Spoel, D.; Weckert, E.; Hajdu, J. Potential for biomolecular imaging with femtosecond X-ray pulses. Nature 2002, 406, 752-757. [CrossRef]

47. Martin-Gracia, J.M.; Conrad, C.E.; Coe, J.; Roy-Chowdhury, S.; Fromme, P. Serial femtosecond crystallography: A revolution in structural biology. Arch. Biochem. Biophys. 2016, 602, 32-47. [CrossRef]

48. Neutze, R.; Huldt, G.; Hajdu, J.; Van Der Spoel, D. Potential impact of an X-ray free electron laser on structural biology. Radiat. Phys. Chem. 2004, 71, 905-916. [CrossRef]

49. Spence, J.C.H. XFELs for structure and dynamics in biology. IUCrJ 2017, 4, 322-339. [CrossRef]

50. Boutet, S.; Lomb, L.; Williams, G.J.; Barends, T.R.; Aquila, A.; Doak, R.B.; Weierstall, U.; DePonte, D.P.; Steinbrener, J.; Shoeman, R.L.; et al. High-resolution protein structure determination by serial femtosecond crystallography. Science 2002, 337, 362-364. [CrossRef]

51. Johansson, L.C.; Arnlund, D.; Katona, G.; White, T.A.; Barty, A.; DePonte, D.P.; Shoeman, R.L.; Wickstrand, C.; Sharma, A.; Williams, G.J.; et al. Structure of a photosynthetic reaction centre determined by serial femtosecond crystallography. Nat. Commun. 2013, 4, 2911. [CrossRef] [PubMed]

52. Ishigami, I.; Zatsepin, N.A.; Hikita, M.; Conrad, C.E.; Nelson, G.; Coe, J.D.; Basu, S.; Grant, T.D.; Seaberg, M.H.; Sierra, R.G.; et al. Crystal structure of CO-bound cytochrome c oxidase determined by serial femtosecond X-ray crystallography at room temperature. Proc. Natl. Acad. Sci. USA 2017, 114, 8011-8016. [CrossRef] [PubMed]

53. Zhang, H.; Han, G.W.; Batyuk, A.; Ishchenko, A.; White, K.L.; Patel, N.; Sadybekov, A.; Zamlynny, B.; Rudd, M.T.; Hollenstein, K.; et al. Structural basis for selectivity and diversity in angiotensin II receptors. Nature 2017, 544, 327-332. [CrossRef] [PubMed] 
54. Fenalti, G.; Zatsepin, N.A.; Betti, C.; Giguere, P.; Han, G.W.; Ishchenko, A.; Liu, W.; Guillemyn, K.; Zhang, H.; James, D.; et al. Structural basis for bifunctional peptide recognition at human $\delta$-opioid receptor. Nat. Struct. Mol. Biol. 2015, 22, 265-268. [CrossRef]

55. Ginn, H.M.; Messerschmidt, M.; Ji, X.; Zhang, H.; Axford, D.; Gildea, R.J.; Winter, G.; Brewster, A.S.; Hattne, J.; Wagner, A.; et al. Structure of CPV17 polyhedrin determined by the improved analysis of serial femtosecond crystallographic data. Nat. Commun. 2015, 6, 6435. [CrossRef]

56. Johansson, L.C.; Stauch, B.; McCorvy, J.D.; Han, G.W.; Patel, N.; Huang, X.P.; Batyuk, A.; Gati, C.; Slocum, S.T.; $\mathrm{Li}, \mathrm{C}$; ; et al. XFEL structures of the human MT2 melatonin receptor reveal the basis of subtype selectivity. Nature 2019, 569, 289-292. [CrossRef]

57. Cheng, R.K.Y.; Abela, R.; Hennig, M. X-ray free electron laser: Opportunities for drug discovery. Essays Biochem. 2017, 61, 529-542. [CrossRef]

58. Mishin, A.; Gusach, A.; Luginina, A.; Marin, E.; Borshchevskiy, V.; Cherezov, V. An outlook on using serial femtosecond crystallography in drug discovery. Expert Opin. Drug Discov. 2019, 14, 933-945. [CrossRef]

59. Ishchenko, A.; Stauch, B.; Han, G.W.; Batyuk, A.; Shiriaeva, A.; Li, C.; Zatsepin, N.; Weierstall, U.; Liu, W.; Nango, E.; et al. Toward G protein-coupled receptor structure-based drug design using X-ray lasers. IUCrJ 2019, 6, 1106-1119. [CrossRef]

60. Nango, E.; Royant, A.; Kubo, M.; Nakane, T.; Wickstrand, C.; Kimura, T.; Tanaka, T.; Tono, K.; Song, C.; Tanaka, R.; et al. A three-dimensional movie of structural changes in bacteriorhodopsin. Science 2016, 354, 1552-1557. [CrossRef]

61. Shimada, A.; Kubo, M.; Baba, S.; Yamashita, K.; Hirata, K.; Ueno, G.; Nomura, T.; Kimura, T.; Shinzawa-Itoh, K.; Baba, J.; et al. A nanosecond time-resolved XFEL analysis of structural changes associated with CO release from cytochrome c oxidase. Sci. Adv. 2017, 3, e1603042. [CrossRef] [PubMed]

62. Kupitz, C.; Basu, S.; Zatsepin, N.; Pande, K.; Milathianaki, D.; Frank, M.; Hunter, M.; Boutet, S.; Williams, G.J.; Koglin, J.E.; et al. Time-resolved serial crystallography captures high-resolution intermediates of photoactive yellow protein. Science 2015, 346, 1242-1246.

63. Kupitz, C.; Basu, S.; Grotjohann, I.; Fromme, R.; Zatsepin, N.A.; Rendek, K.N.; Hunter, M.S.; Shoeman, R.L.; White, T.A.; Wang, D.; et al. Serial time-resolved crystallography of photosystem II using a femtosecond X-ray laser. Nature 2014, 513, 261-265. [CrossRef] [PubMed]

64. White, T.A. Crystallographic data processing for free-electron laser sources. Acta Crystallogr. Sect. D Biol. Crystallogr. 2013, 69, 1231-1240. [CrossRef]

65. Martiel, I.; Muller-Werkmeister, H.M.; Cohen, A.E. Strategies for sample delivery for femtosecond crystallography. Acta Cryst. 2019, D75, 160-177. [CrossRef]

66. Grünbein, M.L.; Kovacs, G.N. Sample delivery for serial crystallography at free-electron lasers and synchrotrons. Acta Cryst. 2019, D75, 178-191. [CrossRef]

67. Sui, S.; Perry, S.L. Microfluidics: From crystallization to serial time-resolved crystallography. Struct Dyn. 2017, 4, 032202. [CrossRef]

68. Southworth-Davies, R.J.; Medina, M.A.; Carmichael, I.; Garman, E.F. Observation of decreased radiation damage at higher dose rates in room temperature protein crystallography. Structure 2007, 15, 1531-1541. [CrossRef]

69. Owen, R.L.; Rudino-Pinera, E.; Garman, E.F. Experimental determination of the radiation dose limit for cryocooled protein crystals. Proc. Natl. Acad. Sci. USA 2006, 103, 4912-4917. [CrossRef]

70. Kupitz, C.; Grotjohann, I.; Conrad, C.; Roy-Chowdhury, S.; Fromme, R.; Fromme, P. Microcrystallization techniques for serial femtosecond crystallography using photosystem II from Thermosynechococcus elongatus as a model system. Philos. Trans. R. Soc. B 2014, 369, 20130316. [CrossRef]

71. Wu, W.; Nogly, P.; Rheinberger, J.; Kick, L.M.; Gati, C.; Nelson, G.; Deupi, X.; Standfuss, J.; Schertler, G.; Panneels, V. Batch crystallization of rhodopsin for structural dynamics using an X-ray free-electron laser. Acta Cryst. 2015, F71, 856-860. [CrossRef] [PubMed]

72. Beale, J.; Bolton, R.; Marshall, S.A.; Beale, E.V.; Carr, S.B.; Ebrahim, A.; Moreno-Chicano, T.; Hough, M.A.; Worrall, J.A.R.; Tews, I.; et al. Successful sample preparation for serial crystallography experiments. J. Appl. Cryst. 2019, 52, 1385-1396. [CrossRef] [PubMed]

73. Lee, D.B.; Kim, J.M.; Seok, J.H.; Lee, J.H.; Jo, J.D.; Mun, J.Y.; Conrad, C.; Coe., J.; Nelson, G.; Hogue, B.; et al. Supersaturation-controlled microcrystallization and visualization analysis for serial femtosecond crystallography. Sci. Rep. 2018, 8, 2541. [CrossRef] [PubMed] 
74. Dods, R.; Båth, P.; Arnlund, D.; Beyerlein, K.R.; Nelson., G.; Liang, M.; Harimoorthy, R.; Berntsen., P.; Malmerberg., E.; Johansson, L.; et al. From Macrocrystals to Microcrystals: A Strategy for Membrane Protein Serial Crystallography. Structure 2017, 25, 1461-1468. [CrossRef]

75. Edlund, P.; Takala, H.; Claesson, E.; Henry, L.; Dods, R.; Lehtivuori, H.; Panman, M.; Pande, K.; White, T.; Nakane, T.; et al. The room temperature crystal structure of a bacterial phytochrome determined by serial femtosecond crystallography. Sci. Rep. 2016, 6, 35279. [CrossRef]

76. Ishchenko, A.; Cherezov, V.; Liu, W. Preparation and Delivery of Protein Microcrystals in Lipidic Cubic Phase for Serial Femtosecond Crystallography. J. Vis. Exp. 2016, Sep 02, 115. [CrossRef]

77. Andersson, R.; Safari, C.; Båth, P.; Bosman, R.; Shilova, A.; Dahl, P.; Ghosh, S.; Dunge, A.; Kjeldsen-Jensen, R.; Nan, J.; et al. Well-based crystallization of lipidic cubic phase microcrystals for serial X-ray crystallography experiments. Acta Crystallogr. D Struct. Biol. 2019, 75, 937-946. [CrossRef]

78. Kolek, S.A.; Bräuning, B.; Steward, P.D. A novel microseeding method for the crystallization of membrane proteins in lipidic cubic phase. Acta Crystallogr. F Struct. Biol. Commun. 2016, 72, 307-312. [CrossRef]

79. Doye, J.P.K.; Poon, W.C.K. Protein crystallization in vivo. Curr. Opin. Colloid Interface Sci. 2006, 11, 40-46. [CrossRef]

80. Gati, C.; Oberthuer, D.; Yefanov, O.; Bunker, R.D.; Stellato, F.; Chiu, E.; Yeh, S.M.; Aquila, A.; Basu, S.; Bean, R.; et al. Atomic structure of granulin determined from native nanocrystalline granulovirus using an $\mathrm{X}$-ray free-electron laser. Proc. Natl. Acad. Sci. USA 2017, 114, 2247-2252. [CrossRef]

81. Koopmann, R.; Cupelli, K.; Redecke, L.; Nass, K.; Deponte, D.P.; White, T.A.; Stellato, F.; Rehders, D.; Liang, M.; Andreasson, J.; et al. In vivo protein crystallization opens new routes in structural biology. Nat. Methods 2012, 9, 259-264. [CrossRef] [PubMed]

82. Gati, C.; Bourenkov, G.; Klinge, M.; Rehders, D.; Stellato, F.; Oberthür, D.; Yefanov, O.; Sommer, B.P.; Mogk, S.; Duszenko, M.; et al. Serial crystallography on in vivo grown microcrystals using synchrotron radiation. IUCrJ 2014, 1, 87-94. [CrossRef] [PubMed]

83. Gallat, F.; Matsugaki, N.; Coussens, N.P.; Yagi, K.J.; Boudes, M.; Higashi, T.; Tsuji, D.; Tatano, Y.; Suzuki, M.; Mizohata, E.; et al. In vivo crystallography at X-ray free electron lasers: The next generation of structural biology? Philos. Trans. R. Soc. B 2014, 369, 20130497. [CrossRef] [PubMed]

84. Sawaya, M.R.; Cascio, D.; Gingery, M.; Rodriguez, J.; Goldschmidt, L.; Colletier, J.P.; Messerschmidt, M.M.; Boutet, S.; Koglin, J.E.; Williams, G.J.; et al. Protein crystal structure obtained at 2.9 Å resolution from injecting bacterial cells into an X-ray free-electron laser beam. Proc. Natl. Acad. Sci. USA 2014, 111, 12769-12774. [CrossRef] [PubMed]

85. Duyvesteyn, H.M.E.; Ginn, H.M.; Peitila, M.K.; Wagner, A.; Hattne, J.; Grimes, J.M.; Hirvonen, E.; Evans, G.; Parsy, M.; Sauter, N.K.; et al. Towards in cellulo virus crystallography. Sci. Rep. 2018, 8, 3771. [CrossRef] [PubMed]

86. Jakobi, A.J.; PAsson, D.M.; Knoops, K.; Stellato, F.; Liang, M.; White, T.A.; Seine, T.; Messerschmidt, M.; Chapman, H.N.; Wilmanns, M. In cellulo serial crystallography of alcohol oxidase crystals inside yeast cells. IUCrJ 2016, 3, 88-95. [CrossRef]

87. Darmanin, C.; Strachan, J.; Adda, C.G.; Thomas, V.; Kobe, B.; Abbey, B. Protein crystal screening and characterization for serial femtosecond nanocrystallography. Sci. Rep. 2016, 6, 25345. [CrossRef]

88. Stevenson, H.P.; DePonte, D.P.; Makhov, A.M.; Conway, J.F.; Zeldin, O.B.; Boutet, S.; Calero, G.; Cohen, A.E. Transmission electron microscopy as a tool for nanocrystal characterization pre- and post-injector. Philos. Trans. R. Soc. B 2014, 369, 20130322. [CrossRef]

89. Barnes, C.O.; Kovaleva, E.G.; Fu, X.; Stevenson, H.P.; Brewster, A.S.; DePonte, D.P.; Baxter, E.L.; Cohen, A.E.; Calero, G. Assessment of microcrystal quality by transmission electron microscopy for efficient serial femtosecond crystallography. Arch. Biochem. Biophys. 2016, 602, 61-68. [CrossRef]

90. Chapman, H.N.; Fromme, P.; Barty, A.; White, T.A.; Kirian, R.A.; Aquila, A.; Hunter, M.S.; Schulz, J.; DePonte, D.P.; Weierstall, U.; et al. Femtosecond X-ray protein nanocrystallography. Nature 2011, 470, 73-78. [CrossRef]

91. Gañán-Calvo, A.M. Generation of Steady Liquid Microthreads and Micron-Sized Monodisperse Sprays in Gas Streams. Phys. Rev. Lett. 1998, 80, 285-288. [CrossRef]

92. DePonte, D.P.; Weierstall, U.; Schmidt, K.; Warner, J.; Starodub, D.; Spence, J.C.H.; Doak, R.B. Gas dynamic virtual nozzle for generation of microscopic droplet streams. J. Phys. D: Appl. Phys. 2008, 41, 195505. [CrossRef] 
93. Doak, R.B.; DePonte, D.P.; Nelson, G.; Camacho-Alanis, F.; Ros, A.; Spence, J.C.H.; Weierstall, U. Microscopic Linear Liquid Streams in Vacuum: Injection of Solvated Biological Samples into X-Ray Free Electron Lasers. AIP Conf. Proc. 2012, 1501, 1314-1323.

94. Weierstall, U. Liquid sample delivery techniques for serial femtosecond crystallography. Philos. Trans. R. Soc. B 2014, 369, 20130337. [CrossRef] [PubMed]

95. Beyerlein, K.R.; Adriano, L.; Heymann, M.; Kirian, R.; Knoska, J.; Wilde, F.; Chapman, H.N.; Bajt, S. Ceramic micro-injection molded nozzles for serial femtosecond crystallography sample delivery. Rev. Sci. Instrum. 2015, 86, 125104. [CrossRef]

96. Weierstall, U.; Spence, J.C.H.; Doak, R.B. Injector for scattering measurements on fully solvated biospecies. Rev. Sci. Instrum. 2012, 83, 035108. [CrossRef]

97. Nelson, G.; Kirian, R.A.; Weierstall, U.; Zatsepin, N.A.; Faragó, T.; Baumbach, T.; Wilde, F.; Niesler, F.B.; Zimmer, B.; Ishigami, I.; et al. Three-dimensional-printed gas dynamic virtual nozzles for x-ray laser sample delivery. Optics Express. 2016, 24, 11515-11530. [CrossRef]

98. Demirci, H.; Sierra, R.G.; Laksmono, H.; Shoeman, R.L.; Botha, S.; Barends, T.R.; Nass, K.; Schlichting, I.; Doak, R.B.; Gati, C.; et al. Serial femtosecond X-ray diffraction of $30 S$ ribosomal subunit microcrystals in liquid suspension at ambient temperature using an X-ray free-electron laser. Acta Crystallogr. Sect. F Struct. Biol. Cryst. Commun. 2013, 69, 1066-1069. [CrossRef]

99. Abdallah, B.G.; Zatsepin, N.A.; Roy-Chowdhury, S.; Coe, J.; Conrad, C.E.; Dörner, K.; Sierra, R.G.; Stevenson, H.P.; Camacho-Alanis, F.; Grant, T.D.; et al. Microfluidic sorting of protein nanocrystals by size for X-ray free-electron laser diffraction. Struct. Dyn. 2015, 2, 041719. [CrossRef]

100. Lomb, L.; Steinbrener, J.; Bari, S.; Beisel, D.; Berndt, D.; Kieser, C.; Lukat, M.; Neef, N.; Shoeman, R.L. An anti-settling sample delivery instrument for serial femtosecond crystallography. J. Appl. Cryst. 2012, 45, 674-678. [CrossRef]

101. Grunbein, M.L.; Bielecki, J.; Gorel, A.; Stricker, M.; Bean, R.; Cammarata, M.; Dörner, K.; Fröhlich, L.; Hartmann, E.; Hauf, S.; et al. Megahertz data collection from protein microcrystals at an X-ray free-electron laser. Nat. Commun. 2018, 9, 3487. [CrossRef] [PubMed]

102. Wiedorn, M.O.; Oberthür, D.; Bean, R.; Schubert, R.; Werner, N.; Abbey, B.; Aepfelbacher, M.; Adriano, L.; Allahgholi, A.; Al-Qudami, N.; et al. Megahertz serial crystallography. Nat. Commun. 2018, 9, 4025. [CrossRef]

103. Oberthuer, D.; Knoška, J.; Wiedorn, M.O.; Beyerlein, K.R.; Bushnell, D.A.; Kovaleva, E.G.; Heymann, M.; Gumprecht, L.; Kirian, R.A.; Barty, A.; et al. Double-flow focused liquid injector for efficient serial femtosecond crystallography. Sci. Rep. 2017, 7, 44628. [CrossRef] [PubMed]

104. Sierra, R.G.; Laksmono, H.; Kern, J.; Tran, R.; Hattne, J.; Alonso, M.; Lassalle-Kaiser, B.; Glöckner, C.; Hellmich, J.; Schafer, D.W.; et al. Nanoflow electrospinning serial femtosecond crystallography. Acta Cryst. 2012, D68, 1584-1587. [CrossRef] [PubMed]

105. Sierra, R.G.; Gati, C.; Laksmono, H.; Dao, E.H.; Gul, S.; Fuller, F.; Kern, J.; Chatterjee, R.; Ibrahim, M.; Brewster, A.S.; et al. Concentric-flow electro kinetic injector enables serial crystallography of ribosome and photosystem I. Nat. Methods 2015, 13, 59-62. [CrossRef] [PubMed]

106. Caffrey, M. A comprehensive review of the lipid cubic phase or in meso method for crystallizing membrane and soluble proteins and complexes. Acta Cryst. 2015, F71, 3-18.

107. Weierstall, U.; James, D.; Wang, C.; White, T.A.; Wang, D.; Liu, W.; Spence, J.C.; Bruce Doak, R.; Nelson, G.; Fromme, P.; et al. Lipidic cubic phase injector facilitates membrane protein serial femtosecond crystallography. Nat. Commun. 2013, 5, 3309. [CrossRef]

108. Shimazu, Y.; Tono, K.; Tanaka, T.; Yamanaka, Y.; Nakane, T.; Mori, C.; Terakado Kimura, K.; Fujiwara, T.; Sugahara, M.; Tanaka, R.; et al. High-viscosity sample injection device for serial femtosecond crystallography at atmospheric pressure. J. Appl. Crystallogr. 2019, 52, 1280-1288. [CrossRef]

109. Fromme, R.; Ishchenko, A.; Metz, M.; Chowdhury, S.R.; Basu, S.; Boutet, S.; Fromme, P.; White, T.A.; Barty, A.; Spence, J.C.; et al. Serial femtosecond crystallography of soluble proteins in lipidic cubic phase. IUCrJ 2015, 2, 545-551. [CrossRef]

110. Nam, K.H. Sample Delivery Media for Serial Crystallography. Int. J. Mol. Sci. 2019, 20, 1094. [CrossRef]

111. Sugahara, M.; Mizohata, E.; Nango, E.; Suzuki, M.; Tanaka, T.; Masuda, T.; Tanaka, R.; Shimamura, T.; Tanaka, Y.; Suno, C.; et al. Grease matrix as a versatile carrier of proteins for serial crystallography. Nat. Methods 2015, 12, 61-63. [CrossRef] [PubMed] 
112. Conrad, C.E.; Basu, S.; James, D.; Wang, D.; Schaffer, A.; Roy-Chowdhury, S.; Zatsepin, N.A.; Aquila, A.; Coe, J.; Gati, C.; et al. A novel inert crystal delivery medium for serial femtosecond crystallography. IUCrJ 2015, 2, 421-430. [CrossRef] [PubMed]

113. Sugahara, M.; Song, C.; Suzuki, M.; Masuda, T.; Inoue, S.; Nakane, T.; Yumoto, F.; Nango, E.; Tanaka, R.; Tono, K.; et al. Oil-free hyaluronic acid matrix for serial femtosecond crystallography. Sci. Rep. 2016, 6, 24484. [CrossRef]

114. Botha, S.; Nass, K.; Barends, T.R.; Kabsch, W.; Latz, B.; Dworkowski, F.; Foucar, L.; Panepucci, E.; Wang, M.; Shoeman, R.L.; et al. Room-temperature serial crystallography at synchrotron X-ray sources using slowly flowing free-standing high-viscosity microstreams. Acta Cryst. 2015, D71, 387-397. [CrossRef]

115. Sugahara, M.; Nakane, T.; Masuda, T.; Suzuki, M.; Inoue, S.; Song, C.; Tanaka, R.; Nakatsu, T.; Mizohata, E.; Yumoto, F.; et al. Hydroxyethyl cellulose matrix applied to serial crystallography. Sci. Rep. 2017, 7, 703. [CrossRef] [PubMed]

116. Kovacsova, G.; Grünbein, M.L.; Kloos, M.; Barends, T.R.M.; Schlesinger, R.; Heberle, J.; Kabsch, W.; Shoeman, R.L.; Doak, R.B.; Schlichting, I. Viscous hydrophilic injection matrices for serial crystallography. IUCrJ 2017, 4, 400-410. [CrossRef]

117. Martin-Gracia, J.M.; Conrad, C.E.; Nelson, G.; Stander, N.; Zatsepin, N.A.; Zook, J.; Zhu, L.; Geiger, J.; Chun, E.; Kissick, D.; et al. Serial millisecond crystallography of membrane and soluble protein microcrystals using synchrotron radiation. IUCrJ 2017, 4, 439-454. [CrossRef]

118. Park, J.; Park, S.; Kim, J.; Park, G.; Cho, Y.; Nam, K.H. Polyacrylamide injection matrix for serial femtosecond crystallography. Sci. Rep. 2019, 9, 2525. [CrossRef]

119. Nam, K.H. Shortening injection matrix for serial crystallography. Sci. Rep. 2020, 10, 107. [CrossRef]

120. Sugahara, M.; Motomura, K.; Suzuki, M.; Masuda, T.; Joti, Y.; Numata, K.; Tono, K.; Yabashi, M.; Ishikawa, T. Viscosity-adjustable grease matrices for serial nanocrystallography. Sci. Rep. 2020, 10, 1371. [CrossRef]

121. James, D.; Weinert, T.; Skopintsev, P.; Furrer, A.; Gashi, D.; Tanaka, T.; Nango, E.; Nogly, P.; Standfuss, J. Improving High Viscosity Extrusion of Microcrystals for Time-resolved Serial Femtosecond Crystallography at X-ray Lasers. J. Vis. Exp. 2019, 144, e59087. [CrossRef] [PubMed]

122. Tosha, T.; Nomura, T.; Nishida, T.; Saeki, N.; Okubayashi, K.; Yamagiwa, R.; Sugahara, M.; Nakane, T.; Yamashita, K.; Hirata, K.; et al. Capturing an initial intermediate during the P450nor enzymatic reaction using time-resolved XFEL crystallography and caged-substrate. Nat. Commun. 2017, 8, 1585. [CrossRef] [PubMed]

123. Audet, M.; White, K.L.; Breton, B.; Zarzycka, B.; Han, G.W.; Lu, Y.; Gati, C.; Batyuk, A.; Popov, P.; Velasquez, J.; et al. Crystal structure of misoprostol bound to the labor inducer prostaglandin E2 receptor. Nat. Chem. Biol. 2019, 15, 11-17. [CrossRef] [PubMed]

124. Luginina, A.; Gusach, A.; Marin, E.; Mishin, A.; Brouillette, R.; Popov, P.; Shiriaeva, A.; Besserer-Offroy, É.; Longpré, J.M.; Lyapina, E.; et al. Structure-based mechanism of cysteinyl leukotriene receptor inhibition by antiasthmatic drugs. Sci. Adv. 2019, 5, eaax2518. [CrossRef] [PubMed]

125. Stauch, B.; Johansson, L.C.; McCorvy, J.D.; Patel, N.; Han, G.W.; Huang, X.P.; Gati, C.; Batyuk, A.; Slocum, S.T.; Ishchenko, A.; et al. Structural basis of ligand recognition at the human MT1 melatonin receptor. Nature 2019, 569, 284-288. [CrossRef] [PubMed]

126. Hunter, M.S.; Segelke, B.; Messerschmidt, M.; Williams, G.J.; Zatsepin, N.A.; Barty, A.; Benner, W.H.; Carlson, D.B.; Coleman, M.; Graf, A.; et al. Fixed-target protein serial microcrystallography with an X-ray free electron laser. Sci. Rep. 2014, 4, 6026. [CrossRef] [PubMed]

127. Park, J.; Joti, Y.; Ishikawa, T.; Song, C. Monte Carlo study for optimal conditions in single-shot imaging with femtosecond x-ray laser pulses. Appl. Phys. Lett. 2013, 103, 264101. [CrossRef]

128. Cohen, A.E.; Soltis, S.M.; González, A.; Aguila, L.; Alonso-Mori, R.; Barnes, C.O.; Baxter, E.L.; Brehmer, W.; Brewster, A.S.; Brunger, A.T.; et al. Goniometer-based femtosecond crystallography with X-ray free electron lasers. Proc. Natl. Acad. Sci. USA 2014, 111, 17122-17127. [CrossRef]

129. Baxter, E.; Aguila, L.; Alonso-Mori, R.; Barnes, C.O.; Bonagura, C.A.; Brehmer, W.; Brunger, A.T.; Calero, G.; Caradoc-Davies, T.T.; Chatterjee, R.; et al. High-density grids for efficient data collection from multiple crystals. Acta Crystallogr. D Struct. Biol. 2016, 72, 2-11. [CrossRef]

130. Zarrine-Afsar, A.; Barends, T.R.; Müller, C.; Fuchs, M.R.; Lomb, L.; Schlichting, I.; Miller, R.J. Crystallography on a chip. Acta Cryst. 2012, D68, 321-323. [CrossRef] 
131. Roedig, P.; Vartiainen, I.; Duman, R.; Panneerselvam, S.; Stübe, N.; Lorbeer, O.; Warmer, M.; Sutton, G.; Stuart, D.I.; Weckert, E.; et al. A micro-patterned silicon chip as sample holder for macromolecular crystallography experiments with minimal background scattering. Sci. Rep. 2015, 5, 10451. [CrossRef] [PubMed]

132. Roedig, P.; Duman, R.; Sanchez-Weatherby, J.; Vartiainen, I.; Burkhardt, A.; Warmer, M.; David, C.; Wagner, A.; Meents, A. Room-temperature macromolecular crystallography using a micro-patterned silicon chip with minimal background scattering. J. Appl. Cryst. 2016, 49, 968-975. [CrossRef] [PubMed]

133. Roedig, P.; Ginn, H.M.; Pakendorf, T.; Sutton, G.; Harlos, K.; Walter, T.S.; Meyer, J.; Fischer, P.; Duman, R.; Vartiainen, I.; et al. High-speed fixed-target serial virus crystallography. Nat. Methods 2017, 14, 805-810. [CrossRef] [PubMed]

134. Lieske, J.; Cerv, M.; Kreida, S.; Komadina, D.; Fischer, J.; Barthelmess, M.; Fischer, P.; Pakendorf, T.; Yefanov, O.; Mariani, V.; et al. On-chip crystallization for serial crystallography experiments and on-chip ligand-binding studies. IUCrJ 2019, 6, 714-728. [CrossRef] [PubMed]

135. Coquelle, N.; Brewster, A.S.; Kapp, U.; Shilova, A.; Weinhausen, B.; Burghammer, M.; Colletier, J. Raster scanning serial protein crystallography using micro- and nano-focused synchrotron beams. Acta Cryst. 2015, D71, 1184-1196. [CrossRef]

136. Murray, T.D.; Lyubimov, A.Y.; Ogata, C.M.; Vo, H.; Uervirojnangkoorn, M.; Brunger, A.T.; Berger, J.M. A high-transparency, micro-patternable chip for X-ray diffraction analysis of microcrystals under native growth conditions. Acta Cryst. 2015, D71, 1987-1997. [CrossRef]

137. Oghbaey, S.; Sarracini, A.; Ginn, H.M.; Pare-Labrosse, O.; Kuo, A.; Marx, A.; Epp, S.W.; Sherrell, D.A.; Eger, B.T.; Zhong, Y.; et al. Fixed target combined with spectral mapping: Approaching 100\% hit rates for serial crystallography. Acta Crystallogr. D Struct. Biol. 2016, 72, 944-955. [CrossRef]

138. Opara, N.; Martiel, I.; Arnold, S.A.; Braun, T.; Stahlberg, H.; Makita, M.; David, C.; Padeste, C. Direct protein crystallization on ultrathin membranes for diffraction measurements at X-ray free-electron lasers. J. Appl. Cryst. 2017, 50, 909-918. [CrossRef]

139. Gicquel, Y.; Schubert, R.; Kapis, S.; Bourenkov, G.; Schneider, T.; Perbandt, M.; Betzel, C.; Chapman, H.N.; Heymann, M. Microfluidic Chips for In Situ Crystal X-ray Diffraction and In Situ Dynamic Light Scattering for Serial Crystallography. J. Vis. Exp. 2018, 134, e57133. [CrossRef]

140. Doak, R.B.; Nass Kovacs, G.; Gorel, A.; Foucar, L.; Barends, T.R.M.; Grünbein, M.L.; Hilpert, M.; Kloos, M.; Roome, C.M.; Shoeman, R.L.; et al. Crystallography on a chip—without the chip: Sheet-on-sheet sandwich. Acta Crystallogr. D Struct. Biol. 2018, 74, 1000-1007. [CrossRef]

141. Sui, S.; Wang, Y.; Kolewe, K.W.; Srajer, V.; Henning, R.; Schiffman, J.D.; Dimitrakopoulos, C.; Perry, S.L. Graphene-based microfluidics for serial crystallography. Lab Chip. 2016, 16, 3082-3096. [CrossRef] [PubMed]

142. Ren, Z.; Ayhan, M.; Bandara, S.; Bowatte, K.; Kumarapperuma, I.; Gunawardana, S.; Shin, H.; Wang, C.; Zeng, X.; Yang, X. Crystal-on-crystal chips for in situ serial diffraction at room temperature. Lab Chip. 2018, 18, 2246-2256. [CrossRef] [PubMed]

143. Lee, D.; Baek, S.; Park, J.; Lee, K.; Kim, J.; Lee, S.J.; Chung, W.K.; Lee, J.L.; Cho, Y.; Nam, K.H. Nylon mesh-based sample holder for fixed-target serial femtosecond crystallography. Sci. Rep. 2019, 9, 6971. [CrossRef] [PubMed]

144. Nass, K. Radiation damage in protein crystallography at X-ray free-electron lasers. Acta Crystallogr. D Struct. Biol. 2019, 75, 211-218. [CrossRef]

145. Lyubimov, A.Y.; Murray, T.D.; Koehl, A.; Araci, I.E.; Uervirojnangkoorn, M.; Zeldin, O.B.; Cohen, A.E.; Soltis, S.M.; Baxter, E.L.; Brewster, A.S.; et al. Capture and X-ray diffraction studies of protein microcrystals in a microfluidic trap array. Acta Crystallogr. D Biol. Crystallogr. 2015, 71, 928-940. [CrossRef]

146. Mueller, C.; Marx, A.; Epp, S.W.; Zhong, Y.; Kuo, A.; Balo, A.R.; Soman, J.; Schotte, F.; Lemke, H.T.; Owen, R.L.; et al. Fixed target matrix for femtosecond time-resolved and in situ serial micro-crystallography. Struct. Dyn. 2015, 2, 054302. [CrossRef]

147. Owen, R.L.; Axford, D.; Sherrell, D.A.; Kuo, A.; Ernst, O.P.; Schulz, E.C.; Miller, R.J.; Mueller-Werkmeister, H.M. Low-dose fixed-target serial synchrotron crystallography. Acta Crystallogr. D Struct. Biol. 2017, 73, 373-378. [CrossRef]

148. Sanchez-Weatherby, J.; Moraes, I. Crystal Dehydration in Membrane Protein Crystallography. In The Next Generation in Membrane Protein Structure Determination; Advances in Experimental Medicine and Biology; Moraes, I., Ed.; Springer: Cham, Switzerland, 2016; Volume 92, pp. 73-89. 
149. Ellson, R.; Mutz, M.; Browning, B.; Lee, L.; Miller, M.F. Roeland Papen Picoliter Inc. Transfer of Low Nanoliter Volumes between Microplates Using Focused Acoustics-Automation Considerations. JALA 2003, 8, $29-34$.

150. Villaseñor, A.G.; Wong, A.; Shao, A.; Garg, A.; Donohue, T.J.; Kuglstatter, A.; Harris, S.F. Nanolitre-scale crystallization using acoustic liquid-transfer technology. Acta Crystallogr. D Biol. Crystallogr. 2012, 68, 893-900. [CrossRef]

151. Villaseñor, A.G.; Wong, A.; Shao, A.; Garg, A.; Kuglstatter, A.; Harris, S.F. Acoustic matrix microseeding: Improving protein crystal growth with minimal chemical bias. Acta Crystallogr. D Biol. Crystallogr. 2010, 66, 568-576. [CrossRef]

152. Yin, X.; Scalia, A.; Leroy, L.; Cuttitta, C.M.; Polizzo, G.M.; Ericson, D.L.; Roessler, C.G.; Campos, O.; Ma, M.Y.; Agarwal, R.; et al. Hitting the target: Fragment screening with acoustic in situ co-crystallization of proteins plus fragment libraries on pin-mounted data-collection micromeshes. Acta Crystallogr. D Biol. Crystallogr. 2014, 70, 1177-1189. [CrossRef] [PubMed]

153. Teplitsky, E.; Joshi, K.; Ericson, D.L.; Scalia, A.; Mullen, J.D.; Sweet, R.M.; Soares, A.S. High throughput screening using acoustic droplet ejection to combine protein crystals and chemical libraries on crystallization plates at high density. J. Struct. Biol. 2015, 191, 49-58. [CrossRef]

154. Collins, P.M.; Ng, J.T.; Talon, R.; Nekrosiute, K.; Krojer, T.; Douangamath, A.; Brandao-Neto, J.; Wright, N.; Pearce, N.M.; von Delft, F. Gentle, fast and effective crystal soaking by acoustic dispensing. Acta Crystallogr. D Struct. Biol. 2017, 73, 246-255. [CrossRef] [PubMed]

155. Soares, A.S.; Engel, M.A.; Stearns, R.; Datwani, S.; Olechno, J.; Ellson, R.; Skinner, J.M.; Allaire, M.; Orville, A.M. Acoustically Mounted Microcrystals Yield High-Resolution X-ray Structures. Biochemistry 2011, 50, 4399-4401. [CrossRef] [PubMed]

156. Samara, Y.N.; Brennan, H.M.; McCarthy, L.; Bollard, M.T.; Laspina, D.; Wlodek, J.M.; Campos, S.L.; Natarajan, R.; Gofron, K.; McSweeney, S.; et al. Using sound pulses to solve the crystal-harvesting Bottleneck. Acta Crystallogr. D Struct. Biol. 2018, 74, 986-999. [CrossRef] [PubMed]

157. Roessler, C.G.; Agarwal, R.; Allaire, M.; Alonso-Mori, R.; Andi, B.; Bachega, J.F.R.; Bommer, M.; Brewster, A.S.; Browne, M.C.; Chatterjee, R.; et al. Acoustic Injectors for Drop-On-Demand Serial Femtosecond Crystallography. Structure 2016, 24, 631-640. [CrossRef] [PubMed]

158. Fuller, F.D.; Gul, S.; Chatterjee, R.; Burgie, E.S.; Young, I.D.; Lebrette, H.; Srinivas, V.; Brewster, A.S.; Michels-Clark, T.; Clinger, J.A.; et al. Drop-on-demand sample delivery for studying biocatalysts in action at X-ray free-electron lasers. Nat. Methods. 2017, 14, 443-449. [CrossRef] [PubMed]

159. Tsujino, S.; Tomizaki, T. Ultrasonic acoustic levitation for fast frame rate X-ray protein crystallography at room temperature. Sci. Rep. 2016, 6, 25558. [CrossRef]

160. Morris, R.H.; Dye, E.R.; Axford, D.; Newton, M.I.; Beale, J.H.; Docker, P.T. Non-Contact Universal Sample Presentation for Room Temperature Macromolecular Crystallography Using Acoustic Levitation. Sci. Rep. 2019, 9, 12431. [CrossRef]

161. Mafuné, F.; Miyajima, K.; Tono, K.; Takeda, Y.; Kohno, J.Y.; Miyauchi, N.; Kobayashi, J.; Joti, Y.; Nango, E.; Iwata, S.; et al. Microcrystal delivery by pulsed liquid droplet for serial femtosecond crystallography. Acta Crystallogr. D Struct. Biol. 2016, 72, 520-523. [CrossRef]

162. Davy, B.; Axford, D.; Beale, J.H.; Butryn, A.; Docker, P.; Ebrahim, A.; Leen, G.; Orville, A.M.; Owen, R.L.; Aller, P. Reducing sample consumption for serial crystallography using acoustic drop ejection. J Synchrotron Radiat. 2019, 26, 1820-1825. [CrossRef] [PubMed]

163. Echelmeier, A.; Kim, D.; Cruz Villarreal, J.; Coe, J.; Quintana, S.; Brehm, G.; Egatz-Gomez, A.; Nazari, R.; Sierra, R.G.; Koglin, J.E.; et al. 3D printed droplet generation devices for serial femtosecond crystallography enabled by surface coating. J. Appl. Crystallogr. 2019, 52, 997-1008. [CrossRef] [PubMed]

164. Brenker, J.C.; Devendran, C.; Neild, A.; Alan, T. On-demand sample injection: Combining acoustic actuation with a tear-drop shaped nozzle to generate droplets with precise spatial and temporal control. Lab Chip. 2019. [CrossRef] [PubMed]

165. Ashtiani, D.; Venugopal, H.; Belousoff, M.; Spicer, B.; Mak, J.; Neild, A.; de Marco, A. Delivery of femtolitre droplets using surface acoustic wave based atomisation for cryo-EM grid preparation. J. Struct. Biol. 2018, 203, 94-101. [CrossRef] 
166. Mathews, I.I.; Allison, K.; Robbins, T.; Lyubimov, A.Y.; Uervirojnangkoorn, M.; Brunger, A.T.; Khosla, C.; DeMirci, H.; McPhillips, S.E.; Hollenbeck, M.; et al. The Conformational Flexibility of the Acyltransferase from the Disorazole Polyketide Synthase Is Revealed by an X-ray Free-Electron Laser Using a Room-Temperature Sample Delivery Method for Serial Crystallography. Biochemistry 2017, 56, 4751-4756. [CrossRef]

167. Awel, S.; Kirian, R.A.; Wiedorn, M.O.; Beyerlein, K.R.; Roth, N.; Horke, D.A.; Oberthür, D.; Knoska, J.; Mariani, V.; Morgan, A.; et al. Femtosecond X-ray diffraction from an aerosolized beam of protein nanocrystals. J. Appl. Crystallogr. 2018, 51, 133-139. [CrossRef]

168. Daurer, B.J.; Okamoto, K.; Bielecki, J.; Maia, F.R.N.C.; Mühlig, K.; Seibert, M.M.; Hantke, M.F.; Nettelblad, C.; Benner, W.H.; Svenda, M.; et al. Experimental strategies for imaging bioparticles with femtosecond hard $\mathrm{X}$-ray pulses. IUCrJ 2017, 4, 251-262. [CrossRef]

169. Schulz, E.C.; Kaub, J.; Busse, F.; Mehrabi, P.; Muller-Werkmeister, H.M.; Pai, E.F.; Robertson, W.D.; Miller, R.J.D. Protein crystals IR laser ablated from aqueous solution at high speed retain their diffractive properties: Applications in high-speed serial crystallography. J. Appl. Cryst. 2017, 50, 1773-1781. [CrossRef]

170. Monteiro, D.C.F.; Vakili, M.; Harich, J.; Sztucki, M.; Meier, S.M.; Horrell, S.; Josts, I.; Trebbin, M. A microfluidic flow-focusing device for low sample consumption serial synchrotron crystallography experiments in liquid flow. J. Synchrotron Radiat. 2019, 26, 406-412. [CrossRef]

171. Stellato, F.; Oberthur, D.; Liang, M.; Bean, R.; Gati, C.; Yefanov, O.; Barty, A.; Burkhardt, A.; Fischer, P.; Galli, L.; et al. Room-temperature macromolecular serial crystallography using synchrotron radiation. IUCrJ 2014, 1, 204-212. [CrossRef]

172. Nam, K.H. Stable sample delivery in viscous media via a capillary for serial crystallography. J. Appl. Cryst. 2020, 53, 45-50. [CrossRef]

173. Moffat, K. Time-Resolved Crystallography. Acta Cryst. 1998, A54, 833-841. [CrossRef] [PubMed]

174. Pan, X.; He, Y.; Huang, X.; Zhao, Y. Crystallographic Snapshots of Class A $\beta$-Lactamase Catalysis Reveal Structural Changes That Facilitate -Lactam Hydrolysis. J. Biol. Chem. 2017, 292, 4022-4033. [CrossRef] [PubMed]

175. Pande, K.; Hutchison, C.D.; Groenhof, G.; Aquila, A.; Robinson, J.S.; Tenboer, J.; Basu, S.; Boutet, S.; DePonte, D.P.; Liang, M.; et al. Femtosecond structural dynamics drives the trans/cis isomerization in photoactive yellow protein. Science 2016, 352, 725-729. [CrossRef]

176. Neutze, R.; Moffat, K. Time-resolved structural studies at synchrotrons and X-ray free electron lasers: Opportunities and challenges. Curr. Opin. Struct. Biol. 2012, 22, 651-659. [CrossRef]

177. Levantino, M.; Yorke, B.A.; Monteiro, D.C.F.; Cammarata, M.; Pearson, A.R. Using synchrotrons and XFELs for time-resolved $\mathrm{X}$-ray crystallography and solution scattering experiments on biomolecules. Curr. Opin. Struct. Biol. 2015, 35, 41-48. [CrossRef]

178. Nogly, P.; James, D.; Wang, D.; White, T.A.; Zatsepin, N.; Shilova, A.; Nelson, G.; Liu, H.; Johansson, L.; Heymann, M.; et al. Lipidic cubic phase serial millisecond crystallography using synchrotron radiation. IUCrJ 2015, 2, 168-176. [CrossRef]

179. Weinert, T.; Olieric, N.; Cheng, R.; Brünle, S.; James, D.; Ozerov, D.; Gashi, D.; Vera, L.; Marsh, M.; Jaeger, K.; et al. Serial millisecond crystallography for routine roomtemperature structure determination at synchrotrons. Nat. Commun. 2017, 8, 542. [CrossRef]

180. Aquila, A.; Hunter, M.S.; Doak, R.B.; Kirian, R.A.; Fromme, P.; White, T.A.; Andreasson, J.; Arnlund, D.; Bajt, S.; Barends, T.R.; et al. Time-resolved protein nanocrystallography using an X-ray free-electron laser. Opt. Express. 2012, 20, 2706-2716. [CrossRef]

181. Suga, M.; Akita, F.; Sugahara, M.; Kubo, M.; Nakajima, Y.; Nakane, T.; Yamashita, K.; Umena, Y.; Nakabayashi, M.; Yamane, T.; et al. Light-induced structural changes and the site of $\mathrm{O}=\mathrm{O}$ bond formation in PSII caught by XFEL. Nature 2017, 543, 131-135. [CrossRef]

182. Tenboer, J.; Basu, S.; Zatsepin, N.; Pande, K.; Milathianaki, D.; Frank, M.; Hunter, M.; Boutet, S.; Williams, G.J.; Koglin, J.E.; et al. Time-resolved serial crystallography captures high-resolution intermediates of photoactive yellow protein. Science 2014, 346, 1242-1246. [CrossRef] [PubMed]

183. Coquelle, N.; Sliwa, M.; Woodhouse, J.; Schirò, G.; Adam, V.; Aquila, A.; Barends, T.R.M.; Boutet, S.; Byrdin, M.; Carbajo, S.; et al. Chromophore twisting in the excited state of a photoswitchable fluorescent protein captured by time-resolved serial femtosecond crystallography. Nat. Chem. 2018, 10, 31-37. [CrossRef] [PubMed] 
184. Nogly, P.; Weinert, T.; James, D.; Carbajo, S.; Ozerov, D.; Furrer, A.; Gashi, D.; Borin, V.; Skopintsev, P.; Jaeger, K.; et al. Retinal isomerization in bacteriorhodopsin captured by a femtosecond x-ray laser. Science 2018, 361, 6398.

185. Barends, T.R.M.; Foucar, L.; Ardevol, A.; Nass, K.; Aquila, A.; Botha, S.; Doak, R.B.; Falahati, K.; Hartmann, E.; Hilpert, M.; et al. Direct observation of ultrafast collective motions in CO myoglobin upon ligand dissociation. Science 2015, 350, 445-450. [CrossRef]

186. Cohen, A.; Doukov, T.; Soltis, M. UV-Visible Absorption Spectroscopy Enhanced X-ray Crystallography at Synchrotron and X-ray Free Electron Laser Sources. Pept. Lett. 2016, 23, 283-290. [CrossRef]

187. Lincoln, C.N.; Fitzpatrick, A.E.; van Thor, J.J. Photoisomerisation quantum yield and non-linear cross-sections with femtosecond excitation of the photoactive yellow protein. Phys. Chem. Chem. Phys. 2012, 14, 15752-15764. [CrossRef]

188. Hutchison, C.D.M.; Kaucikas, M.; Tenboer, J.; Kupitz, C.; Moffat, K.; Schmidt, M.; van Thor, J.J. Photocycle populations with femtosecond excitation of crystalline photoactive yellow protein. Chem. Phys. Lett. 2016, 654, 63-71. [CrossRef]

189. Harmand, M.; Coffee, R.; Bionta, M.R.; Chollet, M.; French, D.; Zhu, D.; Fritz, D.M.; Lemke, H.T.; Medvedev, N.; Ziaja, B.; et al. Achieving few-femtosecond time-sorting at hard X-ray free-electron lasers. Nat. Photonics 2013, 7, 215-218. [CrossRef]

190. Hartmann, N.; Helml, W.; Galler, A.; Bionta, M.R.; Grunert, J.; Molodtsov, S.L.; Ferguson, K.R.; Schorb, S.; Swiggers, M.L.; Carron, S.; et al. Sub-femtosecond precision measurement of relative X-ray arrival time for free-electron lasers. Nat. Photonics 2014, 8, 706-709. [CrossRef]

191. Keedy, D.A.; Kenner, L.R.; Warkentin, M.; Woldeyes, R.A.; Hopkins, J.B.; Thompson, M.C.; Brewster, A.S.; Van Benschoten, A.H.; Baxter, E.L.; Uervirojnangkoorn, M.; et al. Mapping the conformational landscape of a dynamic enzyme by multitemperature and XFEL crystallography. eLife 2015, 4, e07574. [CrossRef]

192. Causgrove, T.P.; Dyer, R.B. Nonequilibrium protein folding dynamics: Laser-induced pH-jump studies of the helix-coil transition. Chem. Phys. 2006, 323, 2-10. [CrossRef]

193. Schmidt, M. Mix and Inject: Reaction Initiation by Diffusion for Time-Resolved Macromolecular Crystallography. Adv. Condensed Matt. Phys. 2013, 167276. [CrossRef]

194. Calvey, G.D.; Katz, A.M.; Schaffer, C.B.; Pollack, L. Mixing injector enables time-resolved crystallography with high hit rate at X-ray free electron lasers. Struct. Dyn. 2016, 3, 054301. [CrossRef] [PubMed]

195. Beyerlein, K.R.; Dierksmeyer, D.; Mariani, V.; Kuhn, M.; Sarrou, I.; Ottaviano, A.; Awel, S.; Knoska, J.; Fuglerud, S.; Jönsson, O.; et al. Mix-and-diffuse serial synchrotron crystallography. IUCrJ 2017, 4, 769-777. [CrossRef]

196. Stagno, J.R.; Bhandari, Y.R.; Conrad, C.E.; Liu, Y.; Wang, Y.X. Real-time crystallographic studies of the adenine riboswitch using an X-ray free-electron laser. FEBS J. 2017, 284, 3374-3380. [CrossRef]

197. Olmos, J.L., Jr.; Pandey, S.; Martin-Garcia, J.M.; Calvey, G.; Katz, A.; Knoska, J.; Kupitz, C.; Hunter, M.S.; Liang, M.; Oberthuer, D.; et al. Enzyme intermediates captured "on the fly" by mix-and-inject serial crystallography. BMC Biol. 2018, 16, 59. [CrossRef]

198. Dasgupta, M.; Budday, D.; de Oliveira, S.H.P.; Madzelan, P.; Marchany-Rivera, D.; Seravalli, J.; Hayes, B.; Sierra, R.G.; Boutet, S.; Hunter, M.S.; et al. Mix-and-inject XFEL crystallography reveals gated conformational dynamics during enzyme catalysis. Proc. Natl. Acad. Sci. USA 2019, 116, 25634-25640. [CrossRef]

199. Knoška, J.; Adriano, L.; Awel, S.; Beyerlein, K.R.; Yefanov, O.; Oberthuer, D.; Peña Murillo, G.E.; Roth, N.; Sarrou, I.; Villanueva-Perez, P.; et al. Ultracompact 3D microfluidics for time-resolved structural biology. Nat Commun. 2020, 11, 657. [CrossRef]

200. Mehrabi, P.; Schulz, E.C.; Agthe, M.; Horrell, S.; Bourenkov, G.; von Stetten, D.; Leimkohl, J.P.; Schikora, H.; Schneider, T.R.; Pearson, A.R.; et al. Liquid application method for time-resolved analyses by serial synchrotron crystallography. Nat. Methods 2019, 16, 979-982. [CrossRef]

201. Opara, N.L.; Mohacsi, I.; Makita, M.; Castano-Diez, D.; Diaz, A.; Juranić, P.; Marsh, M.; Meents, A.; Milne, C.J.; Mozzanica, A.; et al. Demonstration of femtosecond X-ray pump X-ray probe diffraction on protein crystals. Struct. Dyn. 2018, 5, 054303. [CrossRef]

202. Chrencik, J.E.; Roth, C.B.; Terakado, M.; Kurata, H.; Omi, R.; Kihara, Y.; Warshaviak, D.; Nakade, S.; Asmar-Rovira, G.; Mileni, M.; et al. Crystal Structure of Antagonist Bound Human Lysophosphatidic Acid Receptor 1. Cell. 2015, 161, 1633-1643. [CrossRef] [PubMed] 
203. Taniguchi, R.; Inoue, A.; Sayama, M.; Uwamizu, A.; Yamashita, K.; Hirata, K.; Yoshida, M.; Tanaka, Y.; Kato, H.E.; Nakada-Nakura, Y.; et al. Structural nsights into ligand recognition by the lysophosphatidic acid receptor LPA 6 . Nature 2017, 548, 356-360. [CrossRef] [PubMed]

204. Hori, T.; Okuno, T.; Hirata, K.; Yamashita, K.; Kawano, Y.; Yamamoto, M.; Hato, M.; Nakamura, M.; Shimizu, T.; Yokomizo, T.; et al. $\mathrm{Na}^{+}$-mimicking ligands stabilize the inactive state of leukotriene $\mathrm{B}_{4}$ receptor BLT1. Nat. Chem. Biol. 2018, 14, 262-269. [CrossRef] [PubMed]

205. Asada, H.; Inoue, A.; Ngako Kadji, F.M.; Hirata, K.; Shiimura, Y.; Im, D.; Shimamura, T.; Nomura, N.; Iwanari, H.; Hamakubo, T.; et al. The Crystal Structure of Angiotensin II Type 2 Receptor with Endogenous Peptide Hormone. Structure 2019, 2126, 30442-30443. [CrossRef] [PubMed]

206. Huang, C.Y.; Olieric, V.; Ma, P.; Panepucci, E.; Diederichs, K.; Wang, M.; Caffrey, M. In meso in situ serial X-ray crystallography of soluble and membrane proteins. Acta Crystallogr. D Biol. Crystallogr. 2015, 71, 1238-1256. [CrossRef]

207. Zander, U.; Hoffmann, G.; Cornaciu, I.; Marquette, J.P.; Papp, G.; Landret, C.; Seroul, G.; Sinoir, J.; Röwer, M.; Felisaz, F.; et al. Automated harvesting and processing of protein crystals through laser photoablation. Acta Crystallogr. D Struct. Biol. 2016, 72, 454-466. [CrossRef]

208. Hirata, K.; Yamashita, K.; Ueno, G.; Kawano, Y.; Hasegawa, K.; Kumasaka, T.; Yamamoto, M. ZOO: An automatic data-collection system for high-throughput structure analysis in protein microcrystallography. Acta Crystallogr. D Struct. Biol. 2019, 75, 138-150. [CrossRef]

209. Keedy, D.A.; van den Bedem, H.; Sivak, D.A.; Petsko, G.A.; Ringe, D.; Wilson, M.A.; Fraser, J.S. Crystal cryocooling distorts conformational heterogeneity in a model Michaelis complex of DHFR. Structure 2014, 22, 899-910. [CrossRef]

210. Fraser, J.S.; van den Bedem, H.; Samelson, A.J.; Lang, P.T.; Holton, J.M.; Echols, N.; Alber, T. Accessing protein conformational ensembles using room-temperature X-ray crystallography. Proc. Natl. Acad. Sci. USA 2011, 108, 16247-16252. [CrossRef]

211. Naitow, H.; Matsuura, Y.; Tono, K.; Joti, Y.; Kameshima, T.; Hatsui, T.; Yabashi, M.; Tanaka, R.; Tanaka, T.; Sugahara, M.; et al. Protein-ligand complex structure from serial femtosecond crystallography using soaked thermolysin microcrystals and comparison with structures from synchrotron radiation. Acta Crystallogr. D Struct. Biol. 2017, 73, 702-709. [CrossRef]

212. Nogly, P.; Panneels, V.; Nelson, G.; Gati, C.; Kimura, T.; Milne, C.; Milathianaki, D.; Kubo, M.; Wu, W.; Conrad, C.; et al. Lipidic cubic phase injector is a viable crystal delivery system for time-resolved serial crystallography. Nat Commun. 2016, 7, 12314. [CrossRef] [PubMed]

213. Stan, C.; Milathianaki, D.; Laksmono, H.; Sierra, R.G.; McQueen, T.A.; Messerschmidt, M.; Williams, G.J.; Koglin, J.E.; Lane, T.J.; Hayes, M.J.; et al. Liquid explosions induced by X-ray laser pulses. Nature Phys. 2016, 2, 966-971. [CrossRef]

214. Apel, A.K.; Cheng, R.K.Y.; Tautermann, C.S.; Brauchle, M.; Huang, C.Y.; Pautsch, A.; Hennig, M.; Nar, H.; Schnapp, G. Crystal Structure of CC Chemokine Receptor 2A in Complex with an Orthosteric Antagonist Provides Insights for the Design of Selective Antagonists. Structure 2019, 27, 427-438. [CrossRef] [PubMed]

215. Hutchison, C.D.M.; Cordon-Preciado, V.; Morgan, R.M.L.; Nakane, T.; Ferreira, J.; Dorlhiac, G.; Sanchez-Gonzalez, A.; Johnson, A.S.; Fitzpatrick, A.; Fare, C.; et al. X-ray free electron laser determination of crystal structures of dark and light states of a reversibly photoswitching fluorescent protein at room temperature. Int. J. Mol. Sci. 2017, 18, 1918. [CrossRef]

216. Rucktooa, P.; Cheng, R.K.Y.; Segala, E.; Geng, T.; Errey, J.C.; Brown, G.A.; Cooke, R.M.; Marshall, F.H.; Doré, A.S. Towards high throughput GPCR crystallography: In Meso soaking of Adenosine $\mathrm{A}_{2 \mathrm{~A}}$ Receptor crystals. Sci. Rep. 2018, 8, 41. [CrossRef]

217. Moreno-Chicano, T.; Ebrahim, A.; Axford, D.; Appleby, M.V.; Beale, J.H.; Chaplin, A.K.; Duyvesteyn, H.M.E.; Ghiladi, R.A.; Owada, S.; Sherrell, D.A.; et al. High-throughput structures of protein ligand complexes at room temperature using serial femtosecond crystallography. IUCrJ 2019, 6, 1074-1085. [CrossRef]

(C) 2020 by the author. Licensee MDPI, Basel, Switzerland. This article is an open access article distributed under the terms and conditions of the Creative Commons Attribution (CC BY) license (http://creativecommons.org/licenses/by/4.0/). 